\title{
Update on emissions and environmental impacts from the international fleet of ships: the contribution from major ship types and ports
}

\author{
S. B. Dalsøren ${ }^{1,3}$, M. S. Eide ${ }^{2}$, Ø. Endresen ${ }^{2}$, A. Mjelde ${ }^{2}$, G. Gravir ${ }^{2}$, and I. S. A. Isaksen ${ }^{1,3}$ \\ ${ }^{1}$ Department of Geosciences, University of Oslo, Norway \\ ${ }^{2}$ Det Norske Veritas, Veritasveien 1, 1322 Høvik, Norway \\ ${ }^{3}$ CICERO, Centre for International Climate and Environmental Research, Oslo, Norway
}

Received: 30 June 2008 - Published in Atmos. Chem. Phys. Discuss.: 21 October 2008

Revised: 12 February 2009 - Accepted: 5 March 2009 - Published: 24 March 2009

\begin{abstract}
A reliable and up-to-date ship emission inventory is essential for atmospheric scientists quantifying the impact of shipping and for policy makers implementing regulations and incentives for emission reduction. The emission modelling in this study takes into account ship type and size dependent input data for 15 ship types and 7 size categories. Global port arrival and departure data for more than 32000 merchant ships are used to establish operational profiles for the ship segments. The modelled total fuel consumption amounts to $217 \mathrm{Mt}$ in 2004 of which $11 \mathrm{Mt}$ is consumed in in-port operations. This is in agreement with international sales statistics. The modelled fuel consumption is applied to develop global emission inventories for $\mathrm{CO}_{2}, \mathrm{NO}_{2}, \mathrm{SO}_{2}, \mathrm{CO}$, $\mathrm{CH}_{4}$, VOC (Volatile Organic Compounds), $\mathrm{N}_{2} \mathrm{O}, \mathrm{BC}$ (Black Carbon) and OC (Organic Carbon). The global emissions from ships at sea and in ports are distributed geographically, applying extended geographical data sets covering about 2 million global ship observations and global port data for 32000 ships. In addition to inventories for the world fleet, inventories are produced separately for the three dominating ship types, using ship type specific emission modelling and traffic distributions.

A global Chemical Transport Model (CTM) was used to calculate the environmental impacts of the emissions. We find that ship emissions is a dominant contributor over much of the world oceans to surface concentrations of $\mathrm{NO}_{2}$ and $\mathrm{SO}_{2}$. The contribution is also large over some coastal zones. For surface ozone the contribution is high over the oceans but clearly also of importance over Western North America (contribution 15-25\%) and Western Europe (5-15\%). The
\end{abstract}

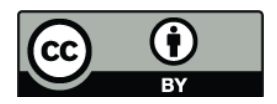

Correspondence to: S. B. Dalsøren (s.b.dalsoren@geo.uio.no) contribution to tropospheric column ozone is up to 5-6\%. The overall impact of ship emissions on global methane lifetime is large due to the high $\mathrm{NO}_{\mathrm{x}}$ emissions. With regard to acidification we find that ships contribute $11 \%$ to nitrate wet deposition and $4.5 \%$ to sulphur wet deposition globally. In certain coastal regions the contributions may be in the range $15-50 \%$.

In general we find that ship emissions have a large impact on acidic deposition and surface ozone in Western North America, Scandinavia, Western Europe, western North Africa and Malaysia/Indonesia. For most of these regions container traffic, the largest emitter by ship type, has the largest impact. This is the case especially for the Pacific and the related container trade routes between Asia and North America. However, the contributions from bulk ships and tank vessels are also significant in the above mentioned impact regions. Though the total ship impact at low latitudes is lower, the tank vessels have a quite large contribution at low latitudes and near the Gulf of Mexico and Middle East. The bulk ships are characterized by large impact in Oceania compared to other ship types. In Scandinavia and northWestern Europe, one of the major ship impact regions, the three largest ship types have rather small relative contributions. The impact in this region is probably dominated by smaller ships operating closer to the coast. For emissions in ports impacts on $\mathrm{NO}_{2}$ and $\mathrm{SO}_{2}$ seem to be of significance. For most ports the contribution to the two components is in the range $0.5-5 \%$, for a few ports it exceeds $10 \%$.

The approach presented provides an improvement in characterizing fleet operational patterns, and thereby ship emissions and impacts. Furthermore, the study shows where emission reductions can be applied to most effectively minimize the impacts by different ship types. 


\section{Introduction}

The world's merchant fleet of 2004 consisted of nearly 91000 ships above 100 gross tonnes (GT), of which cargocarrying ships account for roughly half (Lloyds Register (LR), 2005). The remaining half is employed in non-trading activities like supporting the offshore and oil industry, fishing and services (e.g. towage, dredging, surveying). Ship transportation accounts for the majority of world global trade volumes (almost 2/3 according to Hoffmann and Kumar (2003), $80 \%$ according to Rodrigue et al. (2006), and is generally considered environmentally friendly compared to other transportation means. Nevertheless, ship emissions generated by the merchant fleet are reported to represent a significant contribution to the global anthropogenic emissions (Endresen et al., 2003, 2007; Eyring et al., 2005; Corbett and Koehler, 1999). The actual levels of emissions from ocean-going ships are subject to an ongoing scientific debate. The debate revolves around whether bunker sale statistics are representative when estimating fuel based emissions, whether input data on engine operation profiles are representative when estimating activity based energy consumption and emissions (Corbett and Koehler, 2003, 2004; Endresen et al., 2002, 2004, 2007; Eyring et al., 2005), and whether the geographical distribution of emissions being used are representative for the world fleet (Corbett and Koehler, 2003; Endresen et al., 2003). This study aims to strengthen the accuracy and validity of activity based ship emissions modelling, using improved modelling tools and data sets.

In this study the emissions from ships in ports on a global scale have been considered for the first time, using voyage data for more than 32,000 ships in the world fleet. Also, the voyage data are used to establish activity profiles with a breakdown on 15 different ship types and 7 size categories, 105 ship segments in all. The calculated activity profiles are combined with ship type and size dependent input data, to estimate energy consumption and emissions. The at sea emissions are then distributed globally based on about 2 million global ship observations, combining unpublished AMVER data and COADS data. The in port emissions are distributed based on a new approach.

The ship emissions affect the concentrations of several components in the atmosphere. This in turn may impact health, ecosystems, building materials and climate. Primary components like particles, $\mathrm{NO}_{2}, \mathrm{CO}, \mathrm{NMVOCs}$ and $\mathrm{SO}_{2}$ may potentially cause problems in coastal areas and harbours with heavy traffic because of their impact on human health at high concentrations (Saxe et al., 2004; EPA, 2003). Previous model studies have found high increases close to the regions with heavy traffic, in particular in the North Sea and the Channel. Model studies in general find $\mathrm{NO}_{2}$ concentrations to be more than doubled along the major world shipping lanes (Endresen et al., 2003; Lawrence and Crutzen, 1999; Dalsøren et al., 2007; Eyring el et al., 2007). Observations from satellite have also indicated high $\mathrm{NO}_{2}$ concentrations along major shipping lanes (Beirle et al., 2004; Richter et al., 2004). Ship plume processes are generally not resolved by global models with a resolution (grid box sizes) of hundred of kilometres. These models therefore smooth out the emissions over larger areas. Detailed chemical box-model studies and measurements increase our understanding of subgrid-scale processes taking place within fresh undiluted plumes. Studies and measurements indicate that plume chemistry have to be better taken into account in the impact modeling (Kasibhatla et al., 2001; Chen et al., 2005; Song et al., 2003; von Glasow et al., 2003). These studies suggest enhanced $\mathrm{NO}_{\mathrm{x}}$ destruction within the ship plumes. It is possible that some models might overestimate the effect of ship emissions on the $\mathrm{NO}_{\mathrm{x}}, \mathrm{OH}$ and ozone budget. Still, the amount of observational data from ship plumes is limited and more data and studies are needed.

Ozone is estimated to be the third most important of the greenhouse gases contributing to warming since the preindustrial era (Ramaswamy et al., 2001). Exposure to high ozone levels are linked to (Mauzerall and Wang, 2001; EPA, 2003; WHO, 2003; HEI, 2004) aggravation of existing respiratory problems like asthma, increased susceptibility (infections, allergens and pollutants), inflammation, chest pain and coughing. Elevated ozone during the growing season may result in reductions in agricultural crops and commercial forest yields, reduced growth, increased susceptibility for disease and visible leaf damage on vegetation (Emberson et al., 2001; Mauzerall and Wang, 2001). Ozone might also damage polymeric materials such as paints, plastics and rubber. Several studies have calculated the ship impact on ozone levels (Endresen et al., 2003; Lawrence and Crutzen, 1999; Dalsøren et al., 2007; Cofala et al., 2007; Derwent et al., 2005; Collins et al., 2007; Eyring et al., 2007) using different emission inventories. Cofala et al. (2007) discuss the European health impacts related to ground level ozone and the contribution from shipping. Observations have indicated that ozone might increase, have a weaker negative trend or even an opposite trend than nearby land emissions over Oceans and semi-polluted coastal regions (Lelieveld et al., 2004; Isaksen et al., 2005; Parrish et al., 2008). As pointed out in these studies increasing ship emissions might be one of several causes for these findings.

The hydroxyl radical $(\mathrm{OH})$ reacts with and removes several pollutants and greenhouse gases; one of them is methane $\left(\mathrm{CH}_{4}\right)$. The $\mathrm{OH}$ abundance itself is in turn highly dependent on some of these pollutants, in particular $\mathrm{CH}_{4}, \mathrm{NO}_{\mathrm{x}}$ and CO (Dalsøren and Isaksen, 2006; Wang and Jacob, 1998; Lelieveld et al., 2002). Whereas $\mathrm{CO}$ and $\mathrm{CH}_{4}$ emissions tend to reduce current global averaged $\mathrm{OH}$ levels, the overall effect of $\mathrm{NO}_{\mathrm{x}}$ emissions are to increase $\mathrm{OH}$ (Dalsøren and Isaksen, 2006). Due to the large $\mathrm{NO}_{\mathrm{x}}$ emissions from shipping, this emission source leads to quite large increase in $\mathrm{OH}$ and reduced methane lifetime (Lawrence and Crutzen, 1999; Endresen et al., 2003; Dalsøren et al., 2007; Eyring et al., 2007). 
$\mathrm{NO}_{\mathrm{x}}$ oxidation by $\mathrm{OH}$ leads to formation of nitrate. When nitrate undergoes dry deposition or rainout it may contribute to euthrophication or acidification in vulnerable ecosystems (Vitousek et al., 1997; Galloway et al., 2004). Sulphur emissions might reduce air quality over land e.g. by contributing to sulphate particles or sulphate deposition. $\mathrm{SO}_{2}$ emissions from shipping are oxidized to sulphate primarily in the aqueous phase (in cloud droplets and sea salt particles) and also in the gas phase by the $\mathrm{OH}$ radical. Scandinavia, coastal countries in Western Europe and the Mediterranean, Northwestern America and partly Eastern America and Asia have been shown to be substantially impacted by ship related acidification. (Endresen et al., 2003; Collins et al. 2007; Dalsøren et al., 2007; Lauer et al., 2007; Marmer and Langmann, 2005). Fewer model studies have been performed on other aerosols (Black carbon (soot), organic carbon, etc) than sulphate (Lauer et al., 2007; Dalsøren et al., 2007). There is much concern about a number of health impacts of the fine and ultra-fine aerosols in polluted areas (Martuzzi et al., 2003; Nel, 2005). Corbett et al. (2007) estimates 20000 to 104000 premature deaths globally related to particles caused by shipping. Aerosols have a direct effect on climate and visibility by scattering and/or absorbing solar radiation thereby influence the radiative balance (Penner et al., 2001; Ramanathan et al., 2001). Aerosols can also act as condensation nuclei, modify cloud properties and precipitation rates and through that have indirect climate effects (Ramanathan et al., 2001). Measurements have revealed both direct and indirect effects of aerosols from ship emissions (Hobbs et al., 2000; Durkee et al., 2000; Ferek et al., 2000; Schreier et al., 2006; Schreier et al., 2007; Devasthale et al., 2006)

Several studies have made estimates on the ship emissions impact on climate for one or more components (Capaldo et al., 1999; Endresen et al., 2003, 2008; Eyring et al., 2007, 2008; Lee et al., 2007; Lauer et al., 2007; Dalsøren et al., 2007; Fuglestvedt et al., 2008; Berntsen and Fugelstvedt, 2008). Fuglestvedt et al. (2008), Berntsen and Fuglestvedt (2008), Endresen et al. (2008) and Eyring et al. (2008) give measures or reviews of the overall impact. The range of values in the studies is wide and the uncertainties are large, in particular for indirect effects. A comparison to the climate impact of other transport sectors was made by Fuglestvedt et al. (2008) and Berntsen and Fuglestvedt (2008). The aircraft sector, a sector with comparable fuel consumption, was also discussed in detail by Sausen et al. (2005).

In this study Sect. 2 describes the emission modelling approach and input parameters, while Sect. 3 present the modelled fuel consumption and emissions. Section 4 is devoted to the geographical distribution of the modelled emissions. The model setup and methods for environmental impact studies are explained briefly in Sect. 5. In Sect. 6 the impact from the fleet (both port and sea operations) is discussed. The first global impact study on inclusion of port emissions can be found in Sect. 7. The results from the new approach quan-

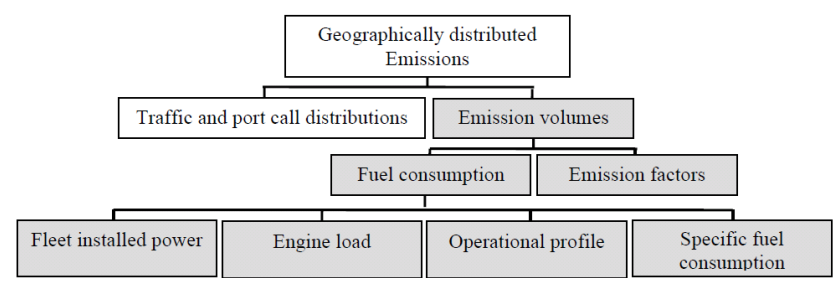

Fig. 1. Concept for activity based fleet emission modelling $\left(\right.$ of $\mathrm{CO}_{2}$, $\mathrm{SO}_{\mathrm{x}}$ etc.). The geographically distributed emissions are used as input to atmospheric models for the assessment of impacts.

tifying individual impacts from major ship types are found in Sect. 8. In Sect. 9 we summarize and highlight the most important findings and outcomes.

\section{Fleet emissions modelling approach}

Different emission modelling approaches are described by EMEP (2002). Endresen et al. (2003, 2007), Corbett and Koehler (2003) and Eyring et al. (2005) have all modelled global emission inventories for shipping. We have estimated the fuel and emissions for the year 2004 world fleet, based on an improved and extended approach of the modelling approach used by Endresen et al. (2003, 2007), Corbett and Koehler (2003) and Eyring et al. (2005). Compared to Endresen et al. $(2003,2007)$ the model presented here has been improved as fleet power is directly calculated using data for individual ships, and that the calculations are broken down on many more ship segments, allowing for greater differentiation. Compared to Eyring et al. (2005) the model presented here uses a greater number of fleet segments, introduces new data on activity profiles and includes detailed modelling of port emissions. The modelling in this study was made for both port and at sea mode (cruising), with a breakdown on 105 different ship types and size segments $(15 \times 7$ matrix $)$. The modelling approach is illustrated in Fig. 1, where the model for emission volumes (grey boxes) are described in this section, while the geographical modelling is presented in Sect. 4.

The exhaust gas emission of pollutant type $g$ from the fleet, $E_{g}$, is given by:

$$
E_{g}=\sum_{i, k, m, s} E_{g, i, k}^{m, s}
$$

With

$$
E_{g, i, k}^{m, s}=c_{g}^{m, s} \bullet F_{i, k}^{m, s}=c_{g}^{m, s} \bullet b_{i, k}^{m, s} \bullet l_{i, k}^{m, s} \bullet t_{i, k}^{m, s} \bullet p_{i, k}^{s}
$$


Table 1. Utilization of installed engine power for ships operating in different modes (\% of Maximum Continuous Rating).

\begin{tabular}{|c|c|c|c|c|c|}
\hline \multirow[t]{2}{*}{ Main Ship type } & \multirow[t]{2}{*}{ Ship type } & \multicolumn{2}{|c|}{ Load at sea ${ }^{1}$} & \multicolumn{2}{|c|}{ Load in port } \\
\hline & & Main engines & AUX & Main engines & AUX \\
\hline \multirow[t]{11}{*}{ Cargo \& Passenger ships } & Bulk Vessels (B) & $70 \%$ & $15 \%$ & $0 \%$ & $20 \%$ \\
\hline & Container Vessels (C) & $70 \%$ & $15 \%$ & $0 \%$ & $20 \%$ \\
\hline & Chemical Tankers (CT) & $70 \%$ & $15 \%$ & $0 \%$ & $40 \%$ \\
\hline & General Cargo (GC) & $70 \%$ & $15 \%$ & $0 \%$ & $20 \%$ \\
\hline & Liquefied Gas Tankers (LGT) & $70 \%$ & $15 \%$ & $0 \%$ & $40 \%$ \\
\hline & Other Service Vessels (OA) & $50 \%$ & $10 \%$ & $0 \%$ & $20 \%$ \\
\hline & Other Liquids (OL) & $70 \%$ & $15 \%$ & $0 \%$ & $40 \%$ \\
\hline & Oil Tankers (OT) & $70 \%$ & $15 \%$ & $0 \%$ & $40 \%$ \\
\hline & Passenger Vessels (P) & $50 \%$ & $20 \%$ & $0 \%$ & $20 \%$ \\
\hline & Reefers (R) & $70 \%$ & $15 \%$ & $0 \%$ & $20 \%$ \\
\hline & Ro Ro Cargo Vessels (RO) & $70 \%$ & $15 \%$ & $0 \%$ & $20 \%$ \\
\hline \multirow[t]{4}{*}{ Non-Cargo Ships } & Offshore Other Vessels (OOA) ${ }^{2)}$ & $50 \%$ & $10 \%$ & $0 \%$ & $20 \%$ \\
\hline & Offshore Supply Vessels (OSV) ${ }^{2}$ & $50 \%$ & $10 \%$ & $0 \%$ & $20 \%$ \\
\hline & TUG & $50 \%$ & $10 \%$ & $0 \%$ & $10 \%$ \\
\hline & Fishing Vessels (FV) & $50 \%$ & $10 \%$ & $0 \%$ & $20 \%$ \\
\hline
\end{tabular}

${ }^{1}$ Includes manoeuvring mode

2 Includes the dynamic position mode.

Where

$E_{g, i, k}^{m, s} \quad$ denotes the amount of pollutant emitted per year of type $g$ for a ship of type $i$ of size $k$ with engine type $s$ (Main engine $=1$, Auxiliary engine $=2)$, at mode $m$ (At sea $=1$, In port $=2)$, $\mathrm{kg}$ pollution.

$c_{g}^{m, s} \quad$ denotes the fuel based emission factor for pollutant type $g$ in mode $m$ for engine type $s, \mathrm{~kg}$ pollution $/ \mathrm{kg}$ fuel.

$F_{i, k}^{m, s} \quad$ denotes the fuel consumption per year of engine type $s$ at mode $m$, of ship type $i$ of size $k, \mathrm{~kg}$ fuel.

$b_{i, k}^{m, s} \quad$ denotes the specific fuel consumption for engine type $s$ at mode $m$, of ship type $i$ of size $k, \mathrm{~kg}$ fuel $/ \mathrm{kWh}$.

$l_{i, k}^{m, s} \quad$ denotes the average engine load for a engine of type $s$ at mode $m$, of ship type $i$ of size $k$.

$t_{i, k}^{m, s} \quad$ denotes the average number of operating hours for engine type $s$ during a year at mode $m$ for vessel of type $i$ and size $k$, hours.

$p_{i, k}^{S} \quad$ denotes average installed engine power for engine type $s$ of ship of type $i$ and size $k, \mathrm{~kW}$.

In the following, a detailed description of the factors in Eq. (2) is given.

\subsection{Fleet installed power}

The actual installed engine power $\left(p_{i, k}^{s}\right)$ for ships above or equal to $100 \mathrm{GT}$ in the year 2004 world fleet is taken from Lloyds Register Fairplay (LRF) (2005) fleet database, counting 91100 merchant ships. The database does not include specific information for Main Engines (ME) for about 15500 ships. For these ships, the installed ME-power is estimated from the ship length by means of statistical relations. The ship type dependent relations are based on data from the remaining 75600 vessels in the world fleet (LRF, 2005). The correlation coefficient varied from 0.6 to 0.97 for the different ship types. In all, the estimated ME power for the 15500 ships accounts for $14 \%$ of the estimated total ME power.

For auxiliary engines (AUX) the database does not include specific information for about 41500 ships. For these ships the AUX power has been estimated using a ship type dependent statistical relation between AUX and ME power, established based on the remaining 49,600 vessels. The correlation coefficient varied from 0.5 to 0.82 for the different ship types. In all, the estimated AUX power for the 41500 ships accounts for $25 \%$ of the estimated total AUX power. This indicates that lack of data is most pronounced with small vessels.

\subsection{Engine load}

The average engine load $\left(l_{i, k}^{m, s}\right)$ varies depending on operational mode (Endresen et al., 2004; Cooper, 2003; EPA, 2000; Flodström, 1997) and the operational mode varies with ship type. The greatest differences are between non-cargo 
and cargo ships, although significant differences exist between ship types within these segments as well. For example, offshore and service vessels often operate several days at sea in the dynamic position mode only utilizing part of the available power (or engines) (Endresen et al., 2004).

Table 1 shows the assumed engine load factor for the different modes and ship type and size categories. The engine load for auxiliary engines in cargo ships operating on different modes is based on Cooper (2003), Whall et al. (2002) and Flodström (1997), and the load set point used in the IMO technical $\mathrm{NO}_{\mathrm{x}}$ Code (IMO, 1998). For tankers the extra energy required during unloading operations has been taken into account. For main engines operating in different modes the engine load is based on data reported by Flodström (1997), Corbett and Koehler (2004), Endresen et al. (2003) and the load set point used in the IMO technical $\mathrm{NO}_{\mathrm{x}}$ Code (IMO, 1998). For non-cargo vessels, the engine load set point is based on data provided by operators as reported by Endresen et al. (2004) and by Corbett and Koehler (2003). The lower engine load for fishing vessels take into account the lower loads during fishing operations. The applied load factors take into account periods with slow cruise, port manoeuvring and ballast cruise that reduce the average engine load.

\subsection{Operation profile}

The average activity profile describes the time, $t_{i, k}^{m, s}$, for each ship type and size category spent in each mode for engine type $\mathrm{s}$ and is based on the average figures compiled from detailed information of individual ship movements of 32000 ships of the world fleet (LMIU, 2004). Each movement record or port call includes information about time at sea and time in port for a given vessel. We have used 617000 individual ship movement records from four months in 2003 (January, April, July and October) to calculate average time at sea and in port for the 7 size categories for 15 ship types. Data filtration removes in the order of 26000 records from the dataset. Furthermore, for approximately 60000 records arrival and departure dates are equal, i.e. the port call lasts less than a day. For these records an average port stay of 0.5 days has been assumed. It is estimated that vessels are in service about 50 weeks per year on average, either at sea or in port. The remaining 2 weeks are time in off-hire (due to e.g. surveys, repairs), where the vessels are laying still, generating no emissions. Publication restrictions attached to the data prohibits full disclosure of the results. In summary, the results show that the number of days at sea varies between 136 days for small bulk vessels to 280 days for large Liquefied Gas Tankers. Ships of the same type show a variation as large as 120 days between size categories. For cargo ships of similar size, the variation is as large as 114 days between ship types. Non-cargo ships of similar size have a variation up to 98 days between ship types.

\section{4 specific fuel consumption and emission factors}

Cooper (2002) has made a detailed survey and evaluation of available emissions factors. He reported factors per ship type and activity mode, which were further used by Whall et al. (2002) to calculate emissions in European waters. We have mainly used the emission factors $\left(c_{g}^{m, s}\right)$ and specific fuel consumption $\left(b_{i, k}^{m, s}\right)$ reported by Cooper (2002) for "At sea "and "In port" mode in our modelling. However, the $\mathrm{SO}_{2}$ emissions factor is adjusted according to the fact that small ships are burning distillates with a typical sulphur content of $0.5 \%$ (EMEP, 2002). We have assumed that all non cargo vessels and all ships in the lowest size categories $(<1000 \mathrm{GT})$ are using fuel with sulphur content of $0.5 \%$. For the vessels operating in the at sea mode emission of $7.6 \mathrm{~kg}$ particulate material (PM) per tonne fuel burned is assumed, in agreement with Whall et al. (2002). However, EMEP (2002) recommend $1.2 \mathrm{~kg}$ PM per tonne distillates burned, and we may therefore overestimate the PM mass emitted. The black carbon (BC) emission factor is assumed to be $0.16 \mathrm{~g} \mathrm{BC} / \mathrm{kg}$ fuel (Sinha et al., 2003), while organic carbon (OC) emissions is assumed to represent $8 \%$ of total PM emitted (Petzold et al., 2003). In accordance with Petzold et al. (2007) it is assumed that $40 \%$ of the PM mass is emitted as sulphate. The applied specific fuel consumption and emission factors are presented in Table 2 and Table 3.

\section{Modelled emission results}

\subsection{Fuel consumption and emission}

The annual fuel consumption $\left(F_{i, k}^{m, s}\right)$ is calculated separately for the at sea mode (including manoeuvring) and in-port mode (e.g. loading/unloading). The resulting total fuel consumption for 2004 is about 217 million tonnes (Mt) of which $11 \mathrm{Mt}$ represent the consumption during in-port operations. Our model indicate that the in port consumption is about 5\% of the total consumption. This is supported by previous estimates that reports in-port emissions to range between $2 \%$ and $6 \%$ of the total emissions (Streets et al., 2000; Whall et al., 2002; Corbett and Koehler, 2003). Detailed results of the fuel calculations are presented in Table 4 . The bulk carriers, container vessels and oil tankers dominate the inventory, accounting for $49 \%$ of the total fuel consumption in the fleet. Note that although half the fleet are non-cargo ships by number, this segment only contribute $15 \%$ of total fleet fuel consumption.

Detailed calculations of the exhaust gas emissions $(\mathrm{Em}, \mathrm{sg}, \mathrm{i}, \mathrm{k})$ for vessels at sea and in port mode are presented in Table 5 and Table 6, respectively. The major part of the air emissions (95\%) are related to vessels operating in the at sea mode. The main contributors, accounting for about half of the emissions are the bulk carriers, container vessels and oil tankers. 
Table 2. Specific fuel consumption and emission factors. For vessels at sea.

\begin{tabular}{llllllllllll}
\hline Vessel type & Fuel g/ kWh & \multicolumn{10}{c}{ Exhaust gas emissions in kg/tonne fuel } \\
\hline & & $\mathrm{NO}_{\mathrm{x}}$ & $\mathrm{SO}_{2} *$ & $\mathrm{CO}_{2}$ & $\mathrm{PM}$ & $\mathrm{NMVOC}$ & $\mathrm{CH}_{4}$ & $\mathrm{~N}_{2} \mathrm{O}$ & $\mathrm{CO}$ & $\mathrm{BC}$ & $\mathrm{OC}$ \\
\hline $\mathrm{B}$ & 196 & 92 & 54 & 3179 & 7.6 & 2.4 & 0.05 & 0.08 & 7.4 & 0.18 & 0.608 \\
$\mathrm{C}$ & 199 & 89 & 54 & 3179 & 7.6 & 2.4 & 0.05 & 0.08 & 7.4 & 0.18 & 0.608 \\
$\mathrm{CT}$ & 203 & 83 & 54 & 3179 & 7.6 & 2.4 & 0.05 & 0.08 & 7.4 & 0.18 & 0.608 \\
$\mathrm{GC}$ & 203 & 81 & 54 & 3179 & 7.6 & 2.4 & 0.05 & 0.08 & 7.4 & 0.18 & 0.608 \\
$\mathrm{LGT}$ & 258 & 41 & 49 & 3179 & 7.6 & 2.4 & 0.05 & 0.08 & 7.4 & 0.18 & 0.608 \\
OA & 222 & 59 & 10 & 3179 & 7.6 & 2.4 & 0.05 & 0.08 & 7.4 & 0.18 & 0.608 \\
OL & 202 & 83 & 54 & 3179 & 7.6 & 2.4 & 0.05 & 0.08 & 7.4 & 0.18 & 0.608 \\
OT & 217 & 75 & 54 & 3179 & 7.6 & 2.4 & 0.05 & 0.08 & 7.4 & 0.18 & 0.608 \\
$\mathrm{P}$ & 219 & 62 & 54 & 3179 & 7.6 & 2.4 & 0.05 & 0.08 & 7.4 & 0.18 & 0.608 \\
$\mathrm{R}$ & 198 & 88 & 54 & 3179 & 7.6 & 2.4 & 0.05 & 0.08 & 7.4 & 0.18 & 0.608 \\
RO & 207 & 76 & 54 & 3179 & 7.6 & 2.4 & 0.05 & 0.08 & 7.4 & 0.18 & 0.608 \\
OOA & 215 & 63 & 10 & 3179 & 7.6 & 2.4 & 0.05 & 0.08 & 7.4 & 0.18 & 0.608 \\
OSV & 212 & 66 & 10 & 3179 & 7.6 & 2.4 & 0.05 & 0.08 & 7.4 & 0.18 & 0.608 \\
TUG & 212 & 65 & 10 & 3179 & 7.6 & 2.4 & 0.05 & 0.08 & 7.4 & 0.18 & 0.608 \\
FV & 215 & 65 & 10 & 3179 & 7.6 & 2.4 & 0.05 & 0.08 & 7.4 & 0.18 & 0.608 \\
\hline
\end{tabular}

NMVOC (Non Methane Volatile Organic Compounds) can be considered as $\mathrm{HC}$ minus $\mathrm{CH}_{4}$, or VOC minus $\mathrm{CH}_{4}\left(\mathrm{Cooper}_{2} 2002\right)$ $10 \mathrm{~kg} /$ tonne fuel applies for vessels $<1000 \mathrm{GT}$

B: Bulk Ship, C: Container Ship, CT: Chemical Tanker, FV: Fishing vessels, GC: General Cargo, LGT: Liquefied Gas Tanker, OA: Other activities, OL: Other Liquids, OOA: Offshore Other Activities, OSV: Offshore Supply Vessel, OT: Oil Tanker, P: Passenger Vessel , R: Reefers, RO: Ro-Ro Cargo, TUG: tugs.

Table 3. Specific fuel consumption and emission factors. For vessels in-port.

\begin{tabular}{llllllllllll}
\hline Vessel type & Fuel g/kWh & \multicolumn{7}{c}{ Exhaust gas emissions in kg/tonne fuel } \\
& & $\mathrm{NO}_{\mathrm{x}}$ & $\mathrm{SO}_{2} *$ & $\mathrm{CO}_{2}$ & $\mathrm{PM}$ & $\mathrm{NMVOC}$ & $\mathrm{CH}_{4}$ & $\mathrm{~N}_{2} \mathrm{O}$ & $\mathrm{CO}$ & $\mathrm{BC}$ & $\mathrm{OC}$ \\
\hline $\mathrm{B}$ & 222 & 62 & 54 & 3179 & 6.8 & 2.4 & 0.05 & 0.08 & 7.4 & 0.18 & 0.54 \\
$\mathrm{C}$ & 223 & 62 & 54 & 3179 & 6.7 & 2.4 & 0.05 & 0.08 & 7.4 & 0.18 & 0.54 \\
$\mathrm{CT}$ & 223 & 60 & 54 & 3179 & 9.7 & 2.4 & 0.05 & 0.08 & 7.4 & 0.18 & 0.78 \\
$\mathrm{GC}$ & 225 & 59 & 54 & 3179 & 6.5 & 2.4 & 0.05 & 0.08 & 7.4 & 0.18 & 0.52 \\
LGT & 278 & 33 & 49 & 3179 & 7.8 & 2.4 & 0.05 & 0.08 & 7.4 & 0.18 & 0.62 \\
OA & 238 & 48 & 10 & 3179 & 7.2 & 2.4 & 0.05 & 0.08 & 7.4 & 0.18 & 0.58 \\
OL & 222 & 60 & 54 & 3179 & 10.0 & 2.4 & 0.05 & 0.08 & 7.4 & 0.18 & 0.8 \\
OT & 237 & 55 & 54 & 3179 & 9.6 & 2.4 & 0.05 & 0.08 & 7.4 & 0.18 & 0.77 \\
P & 236 & 50 & 54 & 3179 & 7.7 & 2.4 & 0.05 & 0.08 & 7.4 & 0.18 & 0.62 \\
R & 225 & 60 & 54 & 3179 & 5.5 & 2.4 & 0.05 & 0.08 & 7.4 & 0.18 & 0.44 \\
RO & 227 & 58 & 54 & 3179 & 6.3 & 2.4 & 0.05 & 0.08 & 7.4 & 0.18 & 0.5 \\
OOA & 232 & 52 & 10 & 3179 & 6.9 & 2.4 & 0.05 & 0.08 & 7.4 & 0.18 & 0.55 \\
OSV & 231 & 52 & 10 & 3179 & 7.5 & 2.4 & 0.05 & 0.08 & 7.4 & 0.18 & 0.6 \\
TUG & 231 & 51 & 10 & 3179 & 7.7 & 2.4 & 0.05 & 0.08 & 7.4 & 0.18 & 0.62 \\
FV & 227 & 59 & 10 & 3179 & 3.6 & 2.4 & 0.05 & 0.08 & 7.4 & 0.18 & 0.29 \\
\hline
\end{tabular}

* $10 \mathrm{~kg} /$ tonne fuel applies for vessels < $1000 \mathrm{GT}$

The fuel consumption and emission figures in this study are valid for the 2004 fleet. However, the maritime industry is currently experiencing a period with rapid growth in global demand for transport, with corresponding increase in ship fuel consumption and emissions. From 2004 to 2007 growth in total seaborne trade in ton miles have been 19\% (Fearnleys, 2008). In the same period, the total installed power in the world fleet increased by about $19 \%$ (LRF, 2008). The increased engine power for the fleet, as well as the increase in trade over the last few years indicate that the year 2004 inventory should be increased with some $19 \%$ to about $258 \mathrm{Mt}$ for an estimate of the 2007 fuel consumption. A corresponding increase in emission is also expected. 
Table 4. Modelled fuel consumption (Kt) for different ship types and modes, 2004.

\begin{tabular}{ccccccc}
\hline Ship type & & No. of vessels & \multicolumn{2}{c}{ Total fuel consumption } & \multicolumn{2}{c}{ Fuel consumption per mode } \\
\hline & & & $\%$ & Kt & At sea (Kt) & In port (Kt) \\
\hline Cargo and Passenger ships & B & 6684 & 13.9 & 30186 & 28874 & 1312 \\
& C & 3237 & 21.7 & 47083 & 45711 & 1371 \\
& CT & 3121 & 4.0 & 8670 & 7726 & 944 \\
& GC & 16729 & 8.9 & 19319 & 18044 & 1275 \\
& LGT & 1190 & 4.5 & 9701 & 9052 & 649 \\
& OA & 4356 & 2.8 & 5982 & 5630 & 352 \\
& OL & 246 & 0.1 & 201 & 171 & 31 \\
& OT & 6873 & 13.7 & 29603 & 27362 & 2241 \\
& P & 7609 & 8.9 & 19250 & 18496 & 754 \\
Non-Cargo Ships & R & 1239 & 2.1 & 4583 & 4315 & 269 \\
& RO & 1504 & 4.7 & 10214 & 9829 & 385 \\
& OOA & 1371 & 1.1 & 2306 & 2101 & 206 \\
TOTAL & OSV & 3564 & 2.7 & 5889 & 5436 & 452 \\
& TUG & 10202 & 4.8 & 10358 & 10269 & 89 \\
& FV & 23194 & 6.1 & 13215 & 12671 & 544 \\
& - & 91119 & 100.0 & 216560 & 205686 & 10874 \\
\hline
\end{tabular}

\subsection{Comparison with other studies}

Endresen et al. (2003, 2007) modelled a fuel consumption for the year 2000 slightly above $200 \mathrm{Mt}$ fuel (including noncargo and AUX consumption). Considering the fleet growth, and assumed corresponding consumption growth up to 2004, our estimates are somewhat lower than Endresen et al. (2003, 2007). Also, our results are well below the $271 \mathrm{Mt}$ and $248 \mathrm{Mt}$ reported for 2001 by Eyring et al. (2005) and Corbett and Koehler (2003) respectively (after subtracting emissions from military vessels). An IMO working group has recently reported a fuel consumption estimate of $369 \mathrm{Mt}$ for 2007 (IMO, 2007). Furthermore, for 2004 EIA (2007) reports marine fuel sales of $226 \mathrm{Mt}$ (we have converted from daily consumption in barrels to annual consumption in tonnes), and IEA (2007) reports a fuel consumption of $206 \mathrm{Mt}$ by the world fleet. It is evident that the results of this study are in closer agreement with the sales figures than with the results of the IMO working group. However, while the activity models exclude ships below $100 \mathrm{GT}$, the fuels statistics makes no such cut-off. Thus, fuel sales statistics should be somewhat higher than the activity model results, in contrast to the present situation.

The deviations between the modelled estimates are likely due to different input data and assumptions (e.g. days at sea and average engine load), which is at the core of the ongoing debate regarding the actual activity level for medium and small ships. It is worth noting that, considering the difference in reference year the estimates of Endresen et al. (2003, 2007) Eyring et al. (2005) and Corbett and Koehler (2003) are in reasonable agreement if one allows for an uncertainty bound in the order of $15 \%$.

\subsection{Uncertainty}

\subsubsection{Model}

The modelling approach used in this study is similar in many ways to previous activity based models. Therefore, many of the identified uncertainties in studies such as Corbett and Koehler (2003) and Endresen et al. (2003, 2007) are valid also for this study, such as the lack of modelling of second order effects among the parameters in equation 2 . However, the fleet breakdown structure used in this study is far more detailed than previous models, reported by Eyring et al. (2005) Corbett and Koehler (2003) and Endresen et al. (2003, 2007). This allows for improved results, provided sufficiently accurate input data.

\subsubsection{Data}

The estimates of uncertainty in the applied data in this study is mostly based on the uncertainty range reported by Endresen et al. (2003, 2007), Eyring et al. (2005) and Corbett and Koehler $(2003,2004)$ due to the many similarities. Endresen et al. (2003) estimates $16 \%$ uncertainty in the fuel consumption estimates. This is in the range of the uncertainty reported for Eyring et al. (2005) and Corbett and Koehler (2003, 2004). While all the factors in Eq. (2) contain uncertainties, focus in this section is on identifying achieved improvements with reference to the previous model estimates.

Corbett and Koehler (2003) identifies engine load factors and days at sea as the most sensitive input parameters to activity based fleet modelling. Admittedly, the current study presents no fundamental improvement on the load factor 


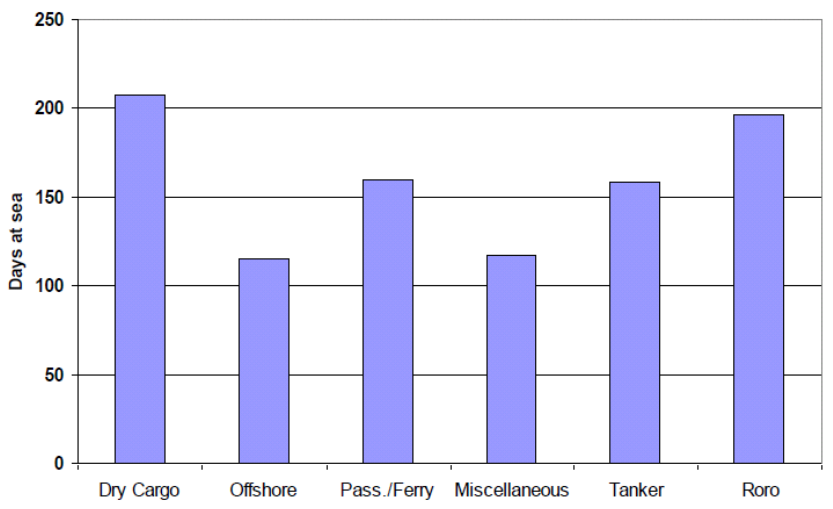

Fig. 2. Calculated yearly days at sea, based on AIS data for 500 small and medium sized ships (above $300 \mathrm{GT}$ ) tracked in Norwegian waters, first six moths of 2007 (data from: The Norwegian Coastal Administration). Note that Offshore ships have low activity, as dynamic position operations are not included.

data. However, with respect to the number of days at sea new data are presented compared to Endresen et al. (2003, 2007), Eyring et al. (2005) and Corbett and Koehler (2003), which are believed to improve the accuracy of the estimates.

The level of detail in the applied fleet database is comparable to that of Eyring et al. (2005) and Corbett and Koehler (2003), and should not result in significant deviations. However, as described in Sect. 2.1, some 14\% of ME and 25\% of AUX fleet power are estimates (using regression), while Eyring et al. (2005) and Corbett and Koehler (2003) do not report missing engine data in the applied fleet database.

The modelling of AUX engine power will likely result in an over-estimation of the AUX fuel consumption since the data contains vessels having diesel electric drive with no AUX engines. It is found that the diesel electric drive represents approximately $3.4 \%$ of the installed main engine power in 2008. The percentage of AUX power in relation to total installed power varies, but lies for the cargo and passenger vessels between $20 \%$ and $30 \%$. This indicates that the overestimation of AUX fuel consumption in the fleet can be in the order of $+0.7 \%$ to $+1.0 \%$ of total fleet consumption.

Although the applied operating profiles are a significant improvement compared to previously used data, uncertainties still remain on this issue. This is illustrated by AIS data from Norwegian waters which shows significant variations between ship types with regard to operating profiles (Fig. 2). These observations indicate that the average engine utilisation factors used in this study (Table 1) may be too high, at least for smaller vessels. It is, however, important to note the validity of the Norwegian AIS data is limited to vessels in coastal traffic, mainly smaller ships.

Endresen et al. (2003) also discuss uncertainty in the applied emission factors. When this is included an uncertainty lower than $20 \%$ is reported for $\mathrm{CO}_{2}, \mathrm{SO}_{2}$ and $\mathrm{NO}_{x}$ emissions, while the other compounds have higher level of uncer- tainty, ranging up to $34 \%$. While no fundamental improvement has been achieved with regard to emission factors, the improved certainty in fuel consumption is transferred directly to the emission estimates.

In total it is believed that an improvement on fuel and emission estimates has been achieved, with an uncertainty as good as or better than Endresen et al. (2003, 2007), Eyring et al. (2005) and Corbett and Koehler (2003).

\section{Geographical distribution of emissions}

\subsection{At-sea emissions}

The modelled atmospheric emissions have been distributed geographically based on the ship reporting frequency and the method reported by Endresen et al. (2003). In this study we use COADS traffic densities for 2000 (COADS, 2005) and the AMVER densities for 2001/2002 (AMVER, 2005). COADS from the National Centre for Atmospheric Research (NCAR) and the National Oceanic and Atmosphere Administration (NOAA), is the most extensive collection of surface marine data available. The global data set has been used by several studies to illustrate global traffic and emissions distributions (Corbett et al., 1999; Endresen et al., 2003), and recently Wang et al. (2007) demonstrated a method to improve global-proxy representativity. In this study, we have used the COADS standard version for 2000 statistically summarised on a monthly basis with a $1^{\circ} \times 1^{\circ}$ spatial resolution. COADS include mainly cargo ships, but also some non-cargo vessel (Endresen et al., 2003). We assume that this data set represents merchant ships operating internationally and regionally. In 2000, a total of 997000 marine reports were registered.

The AMVER system is used to track merchant vessels at sea. These ships submit information including position to the AMVER database. Participation in AMVER is generally limited to merchant ships of all flags above $1000 \mathrm{GT}$, on a voyage of $24 \mathrm{~h}$ or longer. The advantage with the AMVER data set over COADS is that ship type and size can be identified. The AMVER system is used to track about $30 \%$ by number of the world cargo and passenger fleet greater than 2000 Dwt (more than 7300 vessels) that daily report to AMVER during voyage (Endresen et al., 2004). The global data set has been used in previous studies to illustrate global traffic distributions, ship emissions and impacts (Endresen et al., 2003; Eyring et al., 2005; Beirle et al., 2004). However, in the Endresen et al. (2003) study, the AMVER data set did not cover a full calendar year. We have now generated a data set starting August 2001 and ending August 2002, covering one complete year of unpublished data. The applied AMVER data (with a $1^{\circ} \times 1^{\circ}$ spatial resolution) includes a total of 993000 marine reports.

In this study we have merged COADS and AMVER data sets of total 1990000 ship observations day by day, and 


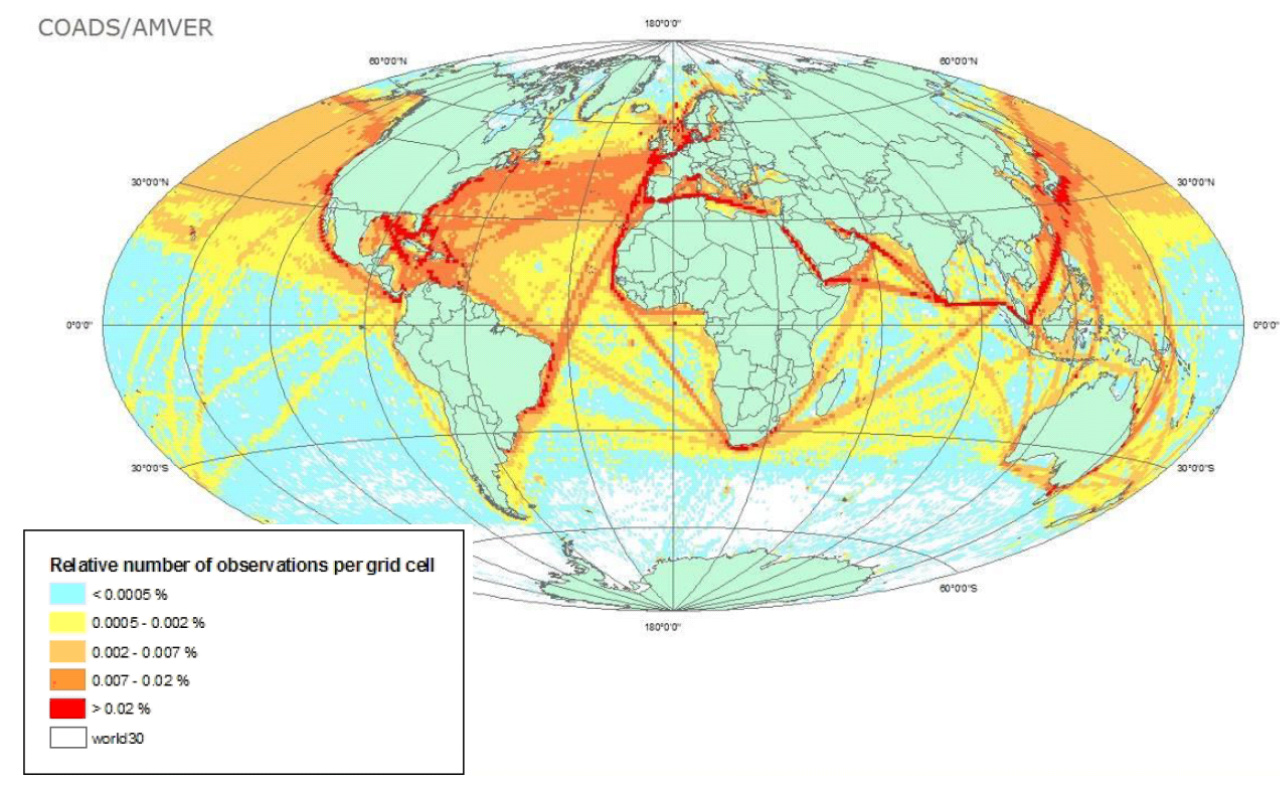

Fig. 3. Geographical distribution of at sea emissions, based on the merged AMVER and COADS data set.
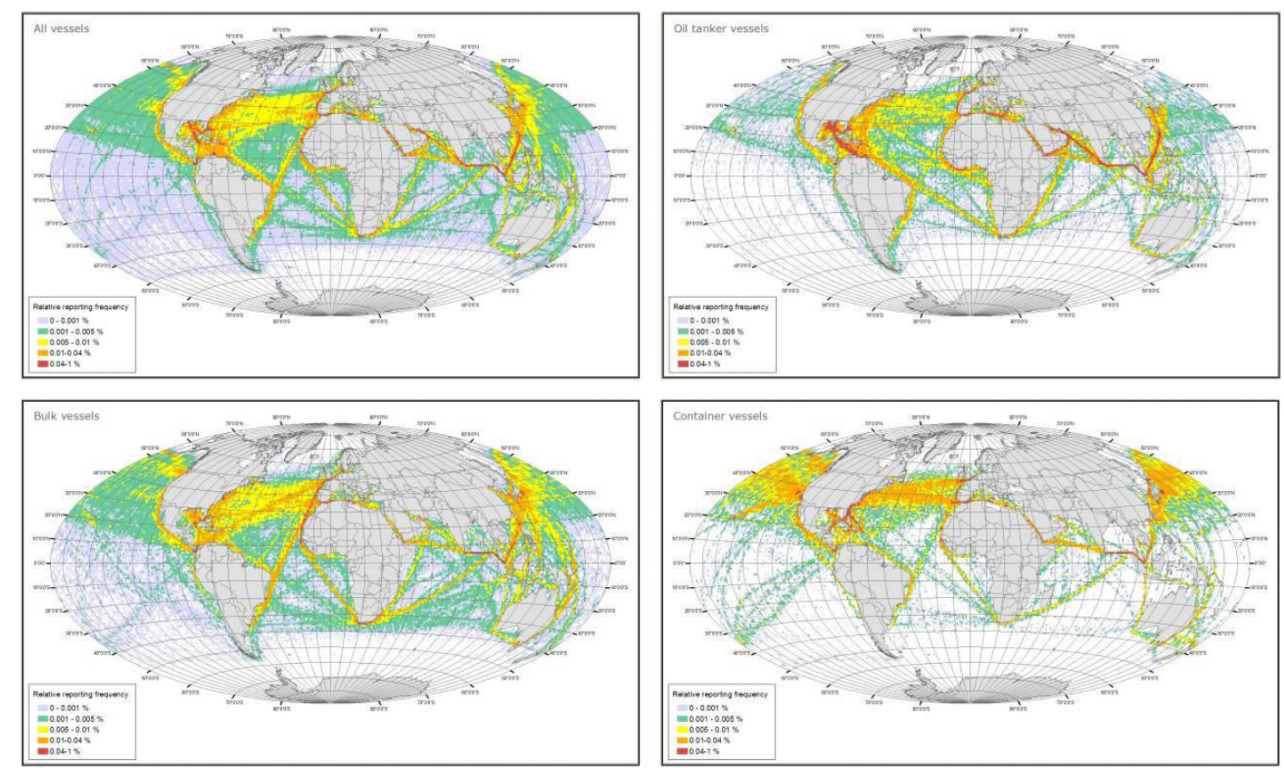

Fig. 4. Vessel traffic densities (relative number of observations per grid cell) for year 2001/2002 based on the AMVER (2005) data. Upper left: All cargo and passenger ships in the AMVER merchant fleet, upper right: Oil tankers, lower left: Bulk carriers, lower right: Container vessels.

produced annual and monthly data sets. These new data sets are represented in a $1^{\circ} \times 1^{\circ}$ spatial resolution. Figure 3 illustrates the merged data set. The emissions generated by the fleet at sea (Table 5) are distributed on the $1^{\circ} \times 1^{\circ}$ grid cells according to the relative number of ship observations in each cell.

Using the AMVER dataset, we have also produced ship type specific geographical emissions distributions for the three major ship types contributing roughly $50 \%$ of the emissions; bulk carriers, tank vessels and container ships (see Ta- ble 5 and 6). The resulting distributions are shown in Fig. 4. The main characteristics of the three ship type specific trades are evident in the Figure. The major bulk cargoes (wet and dry) are mainly transported in large vessels within a fairly well defined system of international sea routes. The major bulk cargoes are fuel, raw materials for industry, and food. By commodity, crude oil represents the biggest share (29\% of total world trade), followed by iron ore (15\%), coal (11\%), oil products $(8 \%)$ and grain (6\%) (Fearnleys, 2008). Asia, North America and Europe are the main import regions of 
Table 5. Modelled exhaust gas emissions at sea for different ship types, 2004 (Kt).

\begin{tabular}{|c|c|c|c|c|c|c|c|c|c|c|c|}
\hline \multicolumn{5}{|l|}{ Ship type } & \multicolumn{7}{|c|}{ Exhaust gas emissions in $\mathrm{Kt}$} \\
\hline & $\mathrm{NO}_{\mathrm{x}}$ & $\mathrm{SO}_{2}$ & $\mathrm{CO}_{2}$ & PM & NMVOC & $\mathrm{CH}_{4}$ & $\mathrm{~N}_{2} \mathrm{O}$ & $\mathrm{CO}$ & $\mathrm{BC}$ & $\mathrm{OC}$ & \\
\hline \multirow[t]{11}{*}{ Cargo \& Passenger ships } & $\mathrm{B}$ & 2656 & 1549 & 91791 & 219 & 69 & 1.4 & 2.3 & 214 & 5.2 & 17.6 \\
\hline & $\mathrm{C}$ & 4068 & 2468 & 145317 & 347 & 110 & 2.3 & 3.7 & 338 & 8.2 & 27.8 \\
\hline & $\mathrm{CT}$ & 641 & 394 & 24560 & 59 & 19 & 0.4 & 0.6 & 57 & 1.4 & 4.7 \\
\hline & GC & 1462 & 876 & 57362 & 137 & 43 & 0.9 & 1.4 & 134 & 3.2 & 11.0 \\
\hline & LGT & 371 & 435 & 28776 & 69 & 22 & 0.5 & 0.7 & 67 & 1.6 & 5.5 \\
\hline & $\mathrm{OA}$ & 332 & 56 & 17896 & 43 & 14 & 0.3 & 0.5 & 42 & 1.0 & 3.4 \\
\hline & OL & 14 & 7 & 543 & 1.3 & 0.4 & 0.01 & 0.01 & 1.3 & 0.03 & 0.1 \\
\hline & OT & 2052 & 1425 & 86983 & 208 & 66 & 1.4 & 2.2 & 202 & 4.9 & 16.6 \\
\hline & $\mathrm{P}$ & 1147 & 808 & 58799 & 141 & 44 & 0.9 & 1.5 & 137 & 3.3 & 11.2 \\
\hline & $\mathrm{R}$ & 380 & 229 & 13716 & 33 & 10 & 0.2 & 0.3 & 32 & 0.8 & 2.6 \\
\hline & $\mathrm{RO}$ & 747 & 528 & 31247 & 75 & 24 & 0.5 & 0.8 & 73 & 1.8 & 6.0 \\
\hline \multirow[t]{4}{*}{ Non-Cargo Ships } & OOA & 132 & 21 & 6678 & 16 & 5 & 0.1 & 0.2 & 16 & 0.4 & 1.3 \\
\hline & OSV & 359 & 54 & 17282 & 41 & 13 & 0.3 & 0.4 & 40 & 1.0 & 3.3 \\
\hline & TUG & 667 & 103 & 32644 & 78 & 25 & 0.5 & 0.8 & 76 & 1.8 & 6.2 \\
\hline & $\mathrm{FV}$ & 824 & 127 & 40281 & 96 & 30 & 0.6 & 1.0 & 94 & 2.3 & 7.7 \\
\hline TOTAL & - & 15853 & 9081 & 653875 & 1563 & 494 & 10 & 16 & 1522 & 37 & 125 \\
\hline
\end{tabular}

Table 6. Exhaust gas emissions in port for different ship types, $2004(\mathrm{Kt})$.

\begin{tabular}{|c|c|c|c|c|c|c|c|c|c|c|c|}
\hline \multirow[t]{2}{*}{ Ship type } & & \multicolumn{10}{|c|}{ Exhaust gas emissions in $\mathrm{Kt}$} \\
\hline & & $\mathrm{NO}_{\mathrm{x}}$ & $\mathrm{SO}_{2}$ & $\mathrm{CO}_{2}$ & PM & NMVOC & $\mathrm{CH}_{4}$ & $\mathrm{~N}_{2} \mathrm{O}$ & $\mathrm{CO}$ & $\mathrm{BC}$ & $\mathrm{OC}$ \\
\hline \multirow[t]{11}{*}{ Cargo \& Passenger ships } & $\mathrm{B}$ & 81 & 71 & 4169 & 8.9 & 3.1 & 0.07 & 0.11 & 9.7 & 0.2 & 0.7 \\
\hline & $\mathrm{C}$ & 85 & 74 & 4359 & 9.2 & 3.3 & 0.07 & 0.11 & 10.1 & 0.2 & 0.7 \\
\hline & $\mathrm{CT}$ & 57 & 51 & 3001 & 9.2 & 2.3 & 0.05 & 0.08 & 7.0 & 0.2 & 0.7 \\
\hline & GC & 75 & 67 & 4053 & 8.3 & 3.1 & 0.06 & 0.10 & 9.4 & 0.2 & 0.7 \\
\hline & LGT & 21 & 30 & 2064 & 5.1 & 1.6 & 0.03 & 0.05 & 4.8 & 0.1 & 0.4 \\
\hline & $\mathrm{OA}$ & 17 & 4 & 1120 & 2.5 & 0.8 & 0.02 & 0.03 & 2.6 & 0.1 & 0.2 \\
\hline & $\mathrm{OL}$ & 2 & 1 & 98 & 0.3 & 0.1 & 0.002 & 0.002 & 0.2 & 0.01 & 0.03 \\
\hline & OT & 123 & 119 & 7126 & 21.5 & 5.4 & 0.11 & 0.18 & 16.6 & 0.4 & 1.7 \\
\hline & $\mathrm{P}$ & 38 & 39 & 2397 & 5.8 & 1.8 & 0.04 & 0.06 & 5.6 & 0.1 & 0.5 \\
\hline & $\mathrm{R}$ & 16 & 14 & 854 & 1.5 & 0.6 & 0.01 & 0.02 & 2.0 & 0.05 & 0.1 \\
\hline & RO & 22 & 21 & 1224 & 2.4 & 0.9 & 0.02 & 0.03 & 2.8 & 0.1 & 0.2 \\
\hline \multirow[t]{4}{*}{ Non-Cargo Ships } & OOA & 11 & 2 & 654 & 1.4 & 0.5 & 0.01 & 0.02 & 1.5 & 0.04 & 0.1 \\
\hline & OSV & 24 & 5 & 1438 & 3.4 & 1.1 & 0.02 & 0.04 & 3.3 & 0.1 & 0.3 \\
\hline & TUG & 5 & 1 & 284 & 0.7 & 0.2 & 0.00 & 0.01 & 0.7 & 0.02 & 0.1 \\
\hline & $\mathrm{FV}$ & 32 & 5 & 1729 & 2.0 & 1.3 & 0.03 & 0.04 & 4.0 & 0.1 & 0.2 \\
\hline TOTAL & - & 609 & 503 & 34569 & 82 & 26 & 0.5 & 0.9 & 80 & 2.0 & 6.6 \\
\hline
\end{tabular}

crude oil (by crude oil carriers). The main exporting regions are the Middle East and Africa. The pattern is different for bulk vessels where the most important import areas are Asia and Europe while the exporting regions are Australia and South America (Fearnleys, 2008). Container shipping is dominated by trades connecting the major economic and industrial regions of the world, namely the US, Europe and South East Asia.

\subsection{Port emissions}

The data from LMIU (2004) described in Sect. 2.3 are used to find a geographical distribution for emissions in port (Table 6). The number of days in each port is calculated based on summarising the time in port for each ship call. The time in port for each call is estimated from "Sail date" minus "Arrival date". Unlike for the determination of operational profiles in Sect. 3.3, no adjustment for records having 


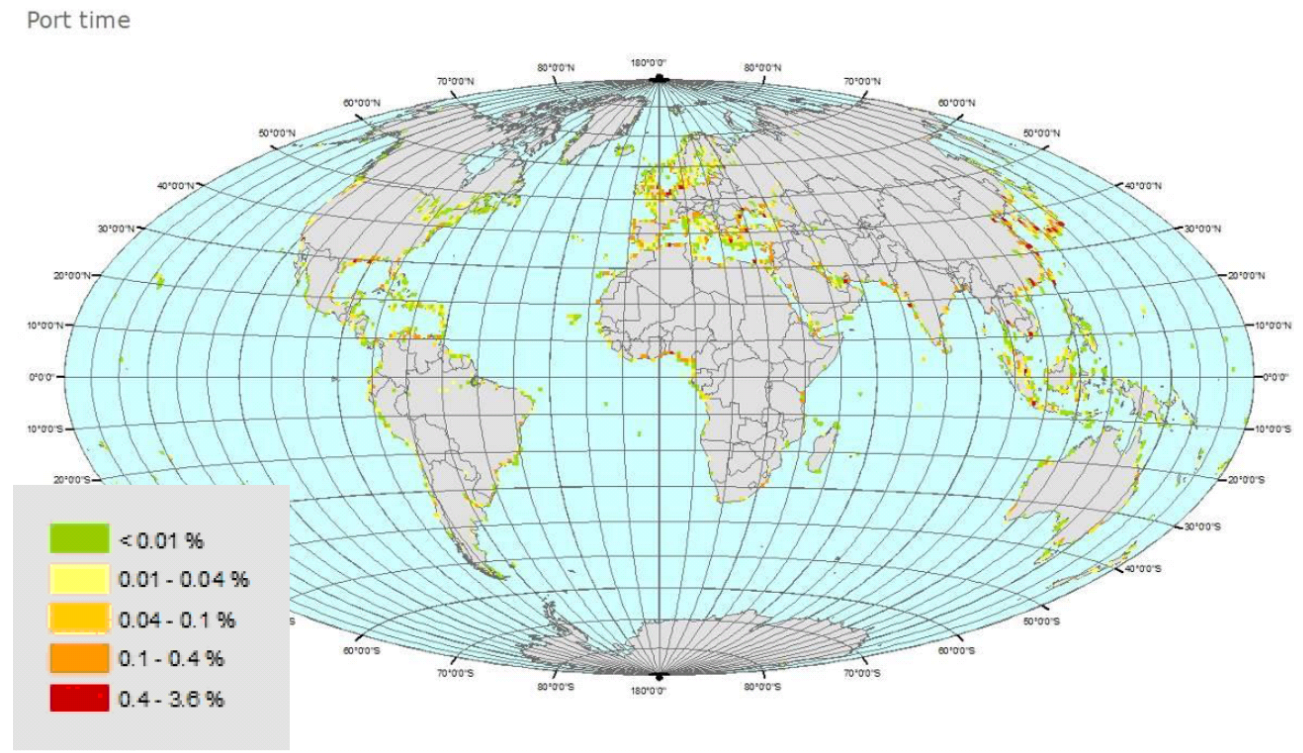

Fig. 5. Geographical distribution of port time (percentage of time in each port relative to total port time), based on the Lloyds' movement data base (LMIU, 2004).

Table 7. Estimated time in port and number of calls per continent (\%) (LMIU, 2004).

\begin{tabular}{lll}
\hline Continent & Time in port $(\%)$ & Port calls $(\%)$ \\
\hline Africa & 9.5 & 6.7 \\
America & 15.1 & 15.0 \\
Asia & 42.2 & 37.1 \\
Europe & 30.5 & 38.7 \\
Australia & 2.7 & 2.5 \\
\hline
\end{tabular}

equal "Sail date" and "Arrival date" is made here. Figure 5 illustrates the global relative distribution of time in port. The emissions generated by ships in port, as found in Table 6, are distributed according to this relative distribution. The fraction of time in a port is calculated using estimated time in the port divided by total time in port for all ports. The Asian ports are dominating, representing $42 \%$ of the total (Table 7). The corresponding number for Europe is $31 \%$.

Table 7 shows that there are some discrepancies between the number of calls and the time in port. For Europe, it is evident that the relative share of time in port is lower than the share of port calls, indicating that the average length of a European port call is shorter than world average. For Asia the trend is the opposite, with the relative time in port higher than the relative number of port calls, suggesting that the length of an average Asian port call is longer than world average. The reasons for such differences are likely related to the typical ship sizes calling at the ports as well as the nature of the typical cargo (e.g. containerized or dry bulk) and the associated differences in cargo handling time. The results in Table 7 in- dicates that building emission inventories for ports using the number of port calls may introduce a bias, underestimating the emissions in large ports, which typically serve very large ships. We claim that our approach, basing the inventories on time in port, increases the accuracy and better reflects the individual port profiles.

\subsection{Uncertainty}

Corbett et al. (1999) illustrated seasonal variations in a COADS data set from 1996. The ship traffic depends on demand for energy, raw material, food etc. This of course gives large variations in the traffic and emissions both on regional and seasonal scale. Our result illustrates significant variations between months, and also between the two data sources (Fig. 6). We find that COADS have highest activity for the coldest months, typically covering the fishing season (Northern Hemisphere). This may be explained with the fact that COADS include many fishing vessels (Endresen et al., 2003). The AMVER distribution is opposite, compared to COADS. This is explained with increased transportation of energy related products (e.g. oil, gas) during autumn for use in the winter season. Also important is seasonal variation in transportation of vegetables, food products and increased demand before major holidays (e.g. Christmas). Note that some of the variation is caused by different number of days within a month (e.g. February). The comparison of monthly activity includes some uncertainty, as different reference years are applied (COADS year 2000, AMVER year 2001/2002). However variation in traffic between different months seems to be as much as $10 \%$, with largest shipping activities in October (Fig. 6). This may be important for impact modelling. 


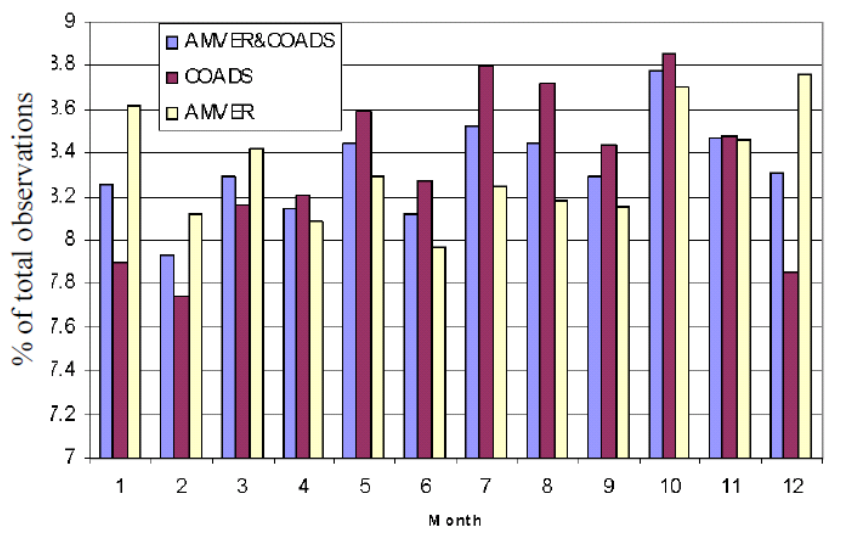

Fig. 6. Ship traffic observation in each month (month $1=\mathrm{Jan}-$ uary) as percentage of total yearly observations, based on AMVER (year 2001/2002) and COADS (year 2000) and AMVER \& COADS (merged). Note that the $\mathrm{y}$-axis is truncated.

It is important to recognize that the significant growth in container trade in recent years, as well as the general increase in ship activity in Asian waters, is changing the geographical distribution of ship traffic. To illustrate, the Chinese ports (including Taiwan Province of China and Hong Kong, China) accounted for 102.1 million TEUs in 2005, representing some $26.6 \%$ of world container port throughput. In 2006 throughput had increased to 118.6 million TEUs, a rise of $16 \%$ over 2005 (UNCTAD, 2007). In addition, from 2000 to 2004 the sales of marine bunker in Asia (and Oceania) increased by $45 \%$ (EIA, 2007). These rapid changes indicate that the present (2008) distribution of shipping traffic may have changed significantly from the distributions used in the current study, both for the traffic distributions and for port time distributions. Clearly, the last years increase in shipping in general, and particular in Asian waters need to be taken into account in upcoming studies.

\section{Modelling of environmental impacts}

In order to quantify the environmental impact of the updated and new emission inventories a set of model simulations were performed with the OsloCTM2 model. The setup is very similar to Dalsøren et al. (2007), the model runs were done in T63 resolution $\left(1.8^{\circ} \times 1.8^{\circ}\right)$ with 19 vertical layers using meteorological data for 1996. Regional impacts could be dependent on the particular year used for transport data. Decisive patterns like NAO and ENSO were not in very strong negative or positive phases in 1996 and though there were some anomalies (WMO, 1997) the year was not deviating strongly from a normal or average year. To quantify the impact of ship types, port emissions and the overall impact from the fleet the analysis compare model runs where each of these emissions sources are excluded from the runs to a simulation where all inventories are included. The model was described and compared to observations in previous ship impact studies (Endresen et al., 2003; Dalsøren et al., 2007). In these studies the calculated impacts of ship emissions were also compared to other model studies and likely causes for similarities and differences were discussed. Overall the model was able to reasonably reproduce available observations in areas affected by ship emissions. But more measurement data are needed to be fully conclusive. This is in particular the case for plume processes and the question referred to in the introduction whether models are able to realistically resolve the outcome of plume processes.

\section{Environmental impact from the whole fleet}

Figure 7 shows the relative average yearly contribution from the whole fleet above $100 \mathrm{GT}$ to the concentration of some primary pollutants. The effect of both sea and port operations are accounted for. The contribution to short-lived components like $\mathrm{SO}_{2}$ and $\mathrm{NO}_{2}$ are confined to oceanic and coastal areas. In the vicinity of the major shipping lanes the ship emissions are the dominant contributor to the modelled surface levels with contribution amounting to $20-70 \%$ for $\mathrm{SO}_{2}$ and $40-90 \%$ for $\mathrm{NO}_{2}$. The contribution is also significant and typically $10-50 \%$ on coastal rims, especially on the west side of the continents at high latitudes (North America, Greenland, Scandinavia). A few hundred kilometres inland from the coasts the shipping contribution to $\mathrm{SO}_{2}$ and $\mathrm{NO}_{2}$ level off rapidly due to chemical transformation to secondary components and faster deposition over land. The relative contribution over land regions is also to some degree dependent on the heterogeneity of land emission sources as relative numbers are shown in Fig. 7. The ship impacts on carbonaceous aerosols are included in Fig. 7. As noted in Sect. 2.4, the emissions of these components are the most uncertain ones and the CTM calculations use a simplified scheme for carbonaceous aerosol distributions. However, the calculations should give some idea of the contribution. The contribution is quite large over remote oceans where the amounts of carbonaceous particles from non-ship sources are small. In a few coastal areas the contribution (5-20\%) could be of some importance for particle pollution.

Ozone is formed in the effluents of the ship stacks and has an important role as a source of hydroxyl radicals the major cleansing agent in the troposphere. As mentioned in the introduction, ozone is also a surface pollutant and an important greenhouse gas. The highest perturbations of surface ozone attributed to ship emissions are found in July. At this time of the year the photochemistry is active at mid latitudes in the Northern Hemisphere where most ship emissions occur. In accordance with theory on the nonlinearity of ozone production (Isaksen et al., 1978; Liu et al., 1987; Lin et al., 1988) the largest ozone increases are found in the regions of the Oceans where the background pollution levels are low. In coastal zones where onshore winds dominate the contribution is also 

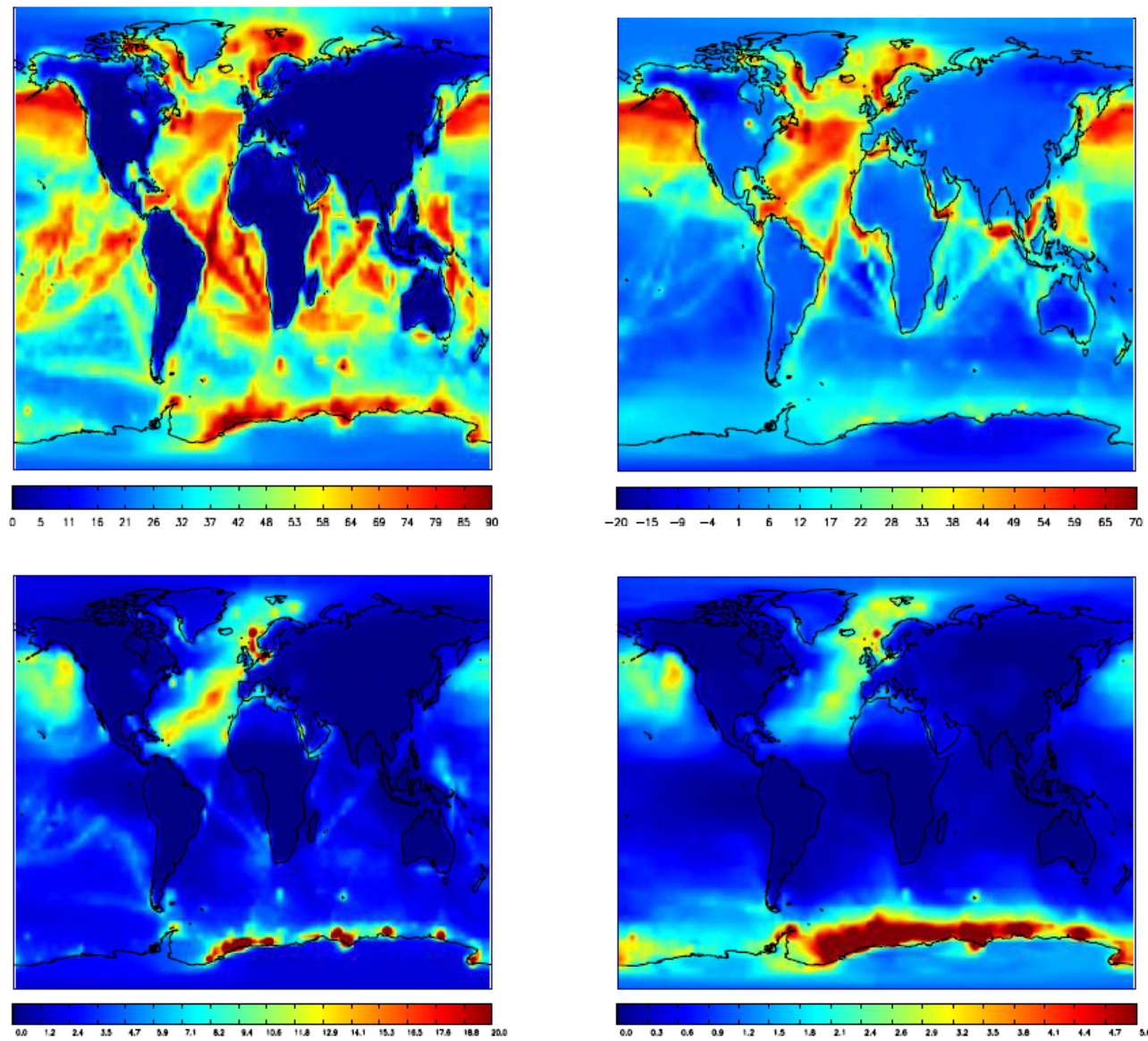

Fig. 7. Yearly average contribution (\%) from all ships+ports to $\mathrm{NO}_{2}$ (upper left) $\mathrm{SO}_{2}$ (upper right), hydrophobic organic carbon (lower left) and hydrophilic organic carbon (lower right).

significant, especially Western North America (15-25\%) and Western Europe (5-15\%). As ozone changes in the upper troposphere are more important with regard to climate forcing (Hansen et al., 1997) the contribution to yearly average tropospheric column (Fig. 8) is more relevant than surface plots. At low southern latitudes, the contribution is approximately 5\% and stronger than at tropical southern latitudes. The main reason is not the pattern of ship traffic (Fig. 3) but that there are less other sources contributing at high southern latitudes. The ship signal at high southern latitudes shows a profound seasonality as most of the traffic takes place during summer. Due to the longer chemical lifetime of ozone in the upper troposphere as well as stronger winds the column perturbation is much more widespread than the surface perturbation. In the Northern Hemisphere ships contribute up to $4-6.5 \%$ to the modelled column ozone over an extensive area. Due to the large sulphur and nitrogen emissions from ships, and successive formation of sulphuric acid and nitric acid which have lifetimes of a few days, acidification over land and coastal regions may occur. In Fig. 8 it is shown that ships alone could contribute as much as $25-50 \%$ to the wet deposition of nitrate over North-Western North America and
Scandinavia. For South-Western Europe and North-Western Africa the contribution is $25-35 \%$. The sulphur deposition is also high in the same regions contributing $15-25 \%$ and $15-$ $20 \%$ respectively. On a global basis we calculate that ship emissions contribute $11 \%$ to nitrate wet deposition and $4.5 \%$ to sulphur wet deposition.

The international fleet increases the global yearly averaged tropospheric $\mathrm{OH}$ levels with $3.67 \%$ (Fig. 9). High $\mathrm{NO}_{\mathrm{x}}$ emissions, in particular over unpolluted regions, together with low $\mathrm{CO}$ and $\mathrm{VOC}$ emissions lead to efficient $\mathrm{OH}$ formation. As quite an amount of the emissions and $\mathrm{OH}$ increase take place over the oceans at low latitudes where the temperatures are high there is a significant impact on the global methane lifetime. The global methane lifetime decreases by $5.35 \%$ (Fig. 9) or $7.5 \%$ if we take into account a feedback factor of 1.4 of methane on its own lifetime (Prather et al., 2001).

\section{Environmental impact of port emissions}

The geographical distribution of time in port is shown in Fig. 5 and the emissions are listed in Table 7. The yearly 

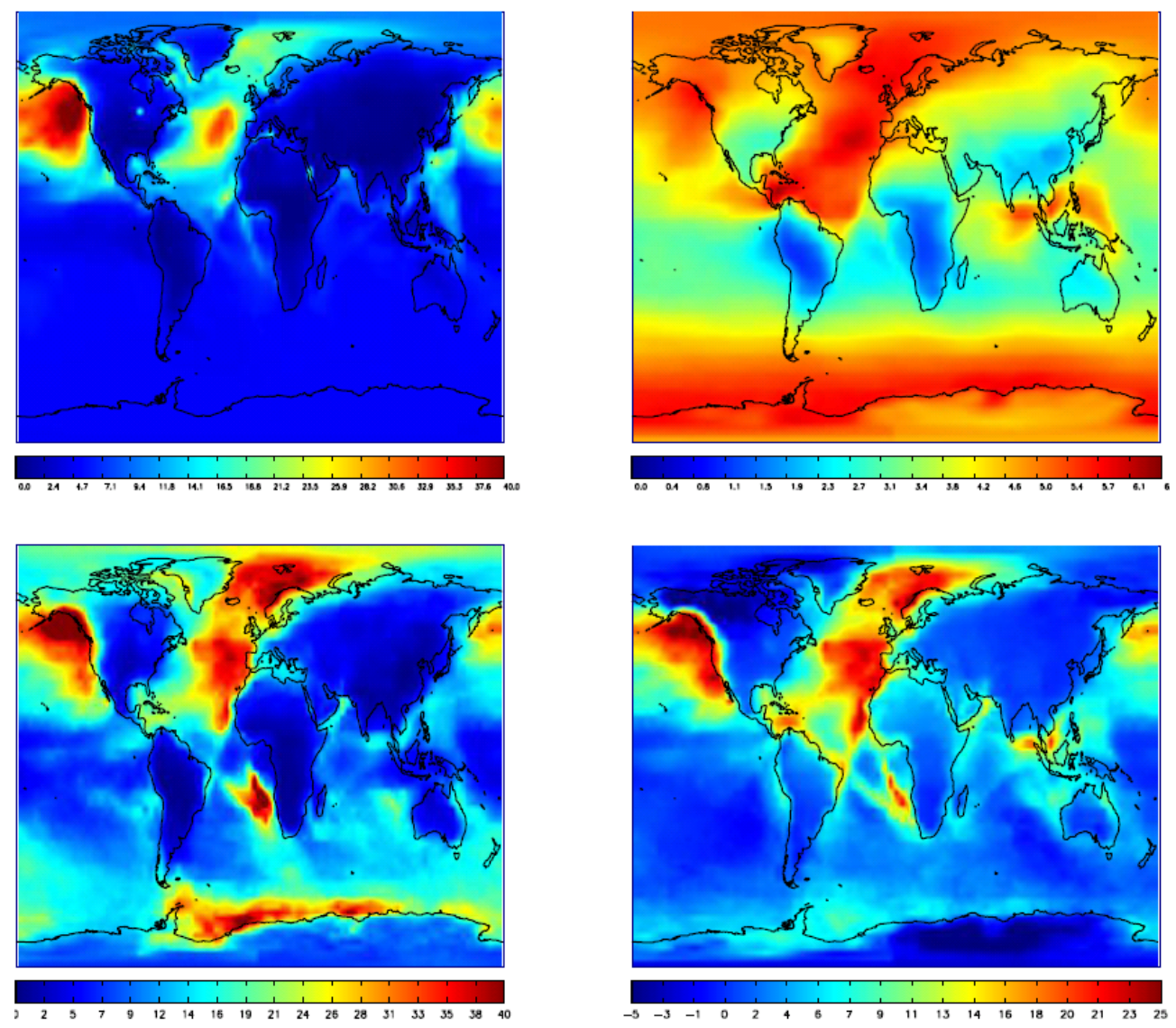

Fig. 8. July average contribution (\%) from all ships+ports to surface ozone (upper left). Yearly average contribution from all ships+ports to tropospheric ozone column (upper right), wet deposition nitrate (lower left) and wet deposition sulphur (lower right).

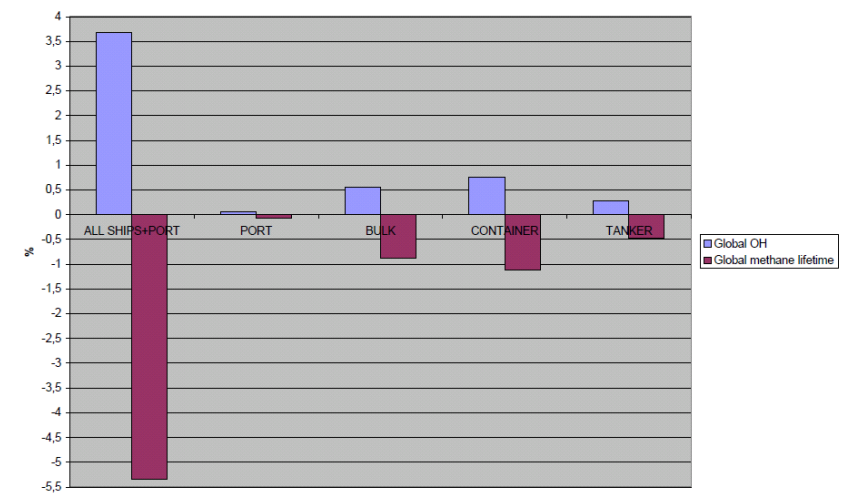

Fig. 9. Changes in $\mathrm{OH}(\%)$ and methane lifetime $(\%)$ compared to simulations where the noted ship-types are excluded.

average contributions from port emissions for the primary components $\mathrm{NO}_{2}$ and $\mathrm{SO}_{2}$ are shown in Fig. 10. The pattern resembles the distribution for the emissions (Fig. 5) though there are some differences as the relative strength of the impact is dependent on other sources in the nearby regions. In regions with high pollution from other sources $\mathrm{NO}_{2}$ pertur- bations due to harbour emissions are small due to non-linear $\mathrm{NO}_{\mathrm{x}}$ chemistry. The relative impacts from some of the major ports in China, Channel area and eastern US are quite small. The contribution to $\mathrm{NO}_{2}$ concentration from some intermediate sized ports situated in regions with quite low background pollution is significant and exceeds $10 \%$ at some places (Fig. 10). For most ports the contribution to $\mathrm{NO}_{2}$ is in the range $0.5-5 \%$. The pattern for $\mathrm{SO}_{2}$ is quite similar, but except for high latitudes the relative contribution is mostly slightly higher than for $\mathrm{NO}_{2}$. Especially in equatorial regions the port emissions contributes to the near surface sulphur loading. In the world's most visited port, Singapore, the contribution from ship emissions to $\mathrm{SO}_{2}$ is larger than $15 \%$. Due to the quite coarse resolution of the global model grid, it is possible that the impacts are averaged out over a too large area. This might for instance be the case for Scandinavia where there is a significant regional impact. However, Scandinavia is situated close to big ports in the Channel, the North Sea and the Baltic Sea and therefore likely to be impacted by both these and intra-regional emissions (Saxe and Larsen, 2004; Isakson et al., 2000). For other components the contribution from port emissions are generally less than $1.5 \%$. An exception is the sulphate levels close to Singapore where 

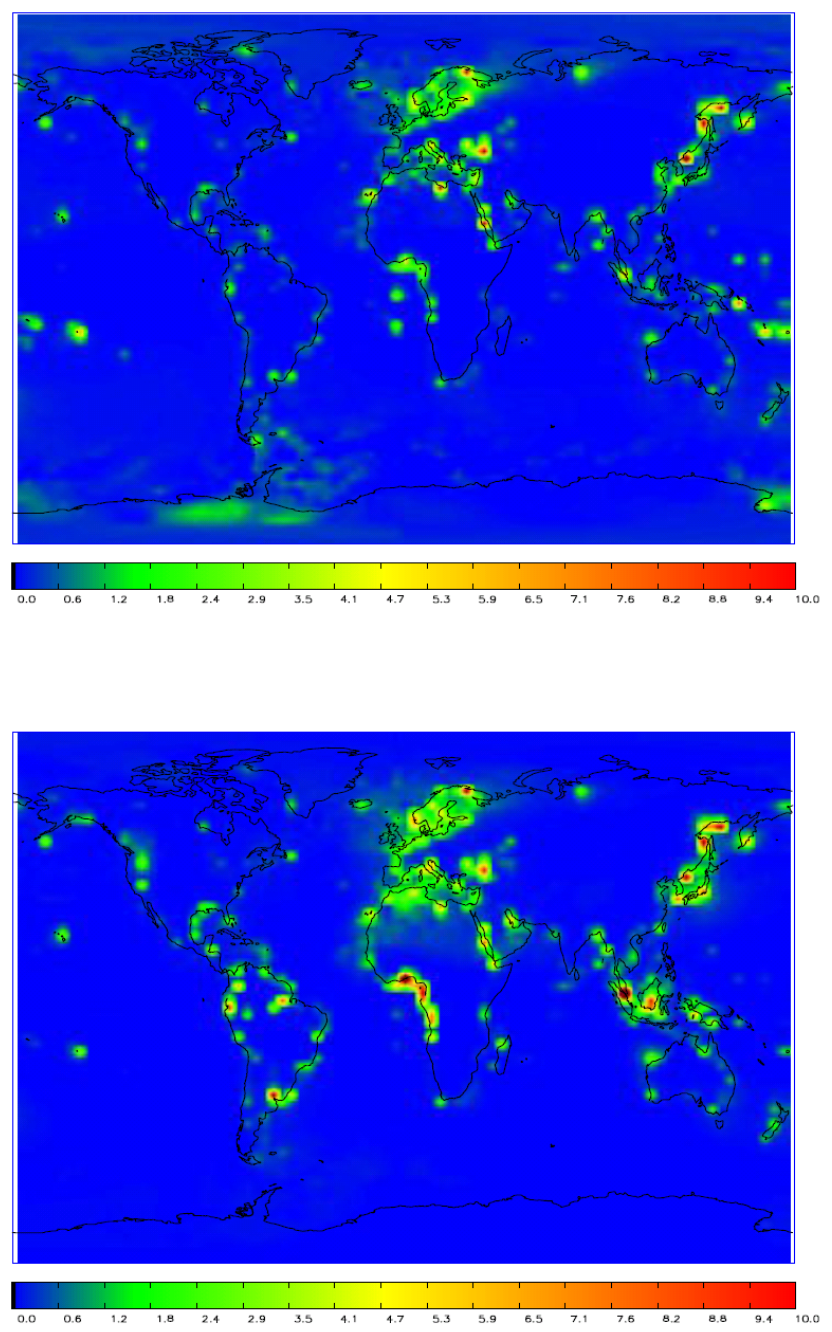

Fig. 10. Yearly average contribution (\%) from ship emissions in ports to $\mathrm{NO}_{2}$ (upper) and $\mathrm{SO}_{2}$ (lower) at the surface.

the port operations contribute a few percent to wet deposition of sulphate. The impact of port emissions on global yearly averaged $\mathrm{OH}$ and methane lifetime is small (Fig. 9). This is mainly due to the small emissions but also likely due to the presence of pollution around population centres making $\mathrm{NO}_{\mathrm{x}}$ perturbations less efficient in affecting OH (Fig. 19).

\section{Environmental impact from major ship types}

In this section we discuss the impacts of the three major ship types; Bulk carriers, tank vessels and container ships. These ship types constitute approximately $50 \%$ of the emissions. Due to their large contribution it is of interest to quantify their impact. With regard to policy issues it is also of interest to see how their different geographical operation profiles (Fig. 4) impact particular regions or vulnerable areas. The traffic pattern (discussed Sect. 4.1) can to a large degree also be found in the impacts (Figs. 11-14). Compared to the two other major ship types, bulk ships show larger impacts in Oceania which is one of the main export regions. The container ships have large impact over the northern mid-latitude Oceans where the trades between the major economic regions of the world take place. The tank vessels are characterized by having their largest impact at low latitudes. Compared to other ship sectors their contribution is strong near the export regions the Gulf of Mexico and the Middle East propagating along the ship-lines of the Indian Ocean towards East Asia.

For surface ozone in July (Fig. 11) the contribution of bulk ships is less than $5 \%$ everywhere. With regard to pollution levels over populated areas the contribution is only a few percent over most coastal regions. The contribution of the container traffic is large over the Atlantic and Pacific Oceans. The contribution is highest over the remote parts of these oceans where $\mathrm{NO}_{\mathrm{x}}$ levels are low and ozone production therefore most sensitive to perturbations. Large impact is found over the Pacific Ocean on the trades between North America and Asia. As discussed in Sect. 4.3, the world container trade is increasing rapidly, especially in Asia. Even from our basis year (2004) until now, increased trade could have increased the impacts from the container trade utterly. Though the contribution from the container traffic decreases rapidly inland from the coast, the container ships seems to have a significant impact on the surface ozone levels in coastal zones of Western North America (Fig. 11). The contribution from the tanker traffic is not large but up to 3-5\% over coastal waters of the Arabian Sea and Gulf of Mexico and consolidates the quite high surface ozone found in these regions. The container traffic has the largest total emissions and has the largest impact. This is especially the case for yearly averaged column ozone (Fig. 12). In the Northern Hemisphere, the container ship emissions seem to contribute to between $1 / 4$ to $1 / 3$ of the ozone column perturbations due to ship emissions (comparison Figs. 8 and 12). The bulk carriers have the largest contribution of the three ship types at high southern latitudes. The contribution is mainly high during the Southern Hemisphere summer when there is traffic to and from Antarctica. The tanker traffic shows enhanced ozone column perturbations near equator, the extent is limited by efficient removal of ozone precursors in the intertropical convergence zone.

Wet deposition of acidic components is most critical over land, estuaries and coastal zones where they may cause acidification in regions with low buffering capacity. Bulk ships contribute up to 3-7\% to wet deposition of nitrate (Fig. 13) on the west coast of America, and also parts of the eastern coast of the continent. The contribution is similar over coastal zones of Europe, Africa and Australia and small regions of Asia. The contribution from oil tankers (Fig. 13) is about similar in the mentioned regions. This is also the case for container ships (Fig. 13), though this traffic has a much larger impact over Western North America and South 

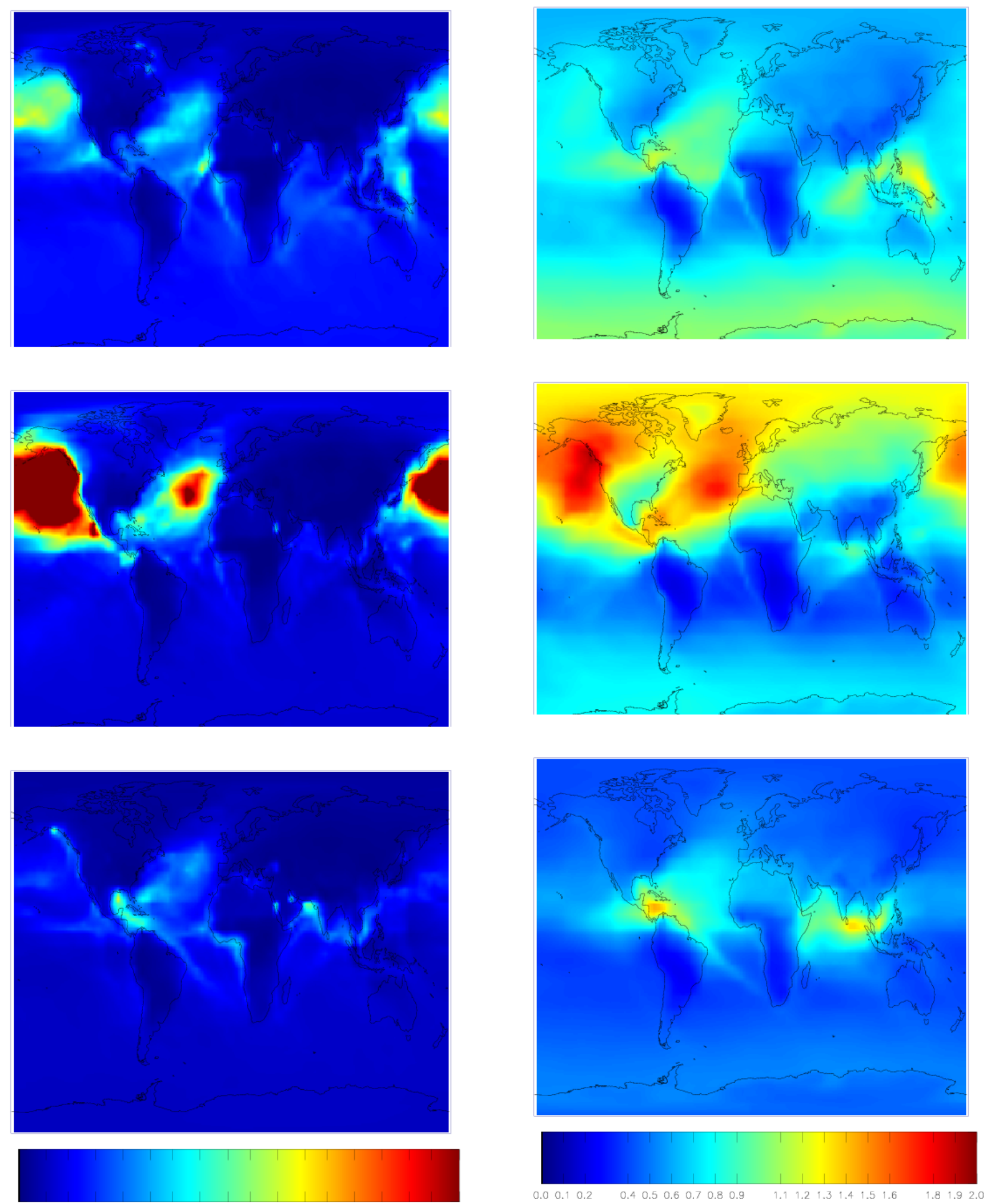

Fig. 12. Yearly average contribution (\%) to tropospheric column

Fig. 11. July average contribution (\%) to surface ozone from bulk ships (upper), container ships (middle) and oil tankers (bottom). ozone from bulk ships (upper), container ships (middle) and oil tankers (bottom). 

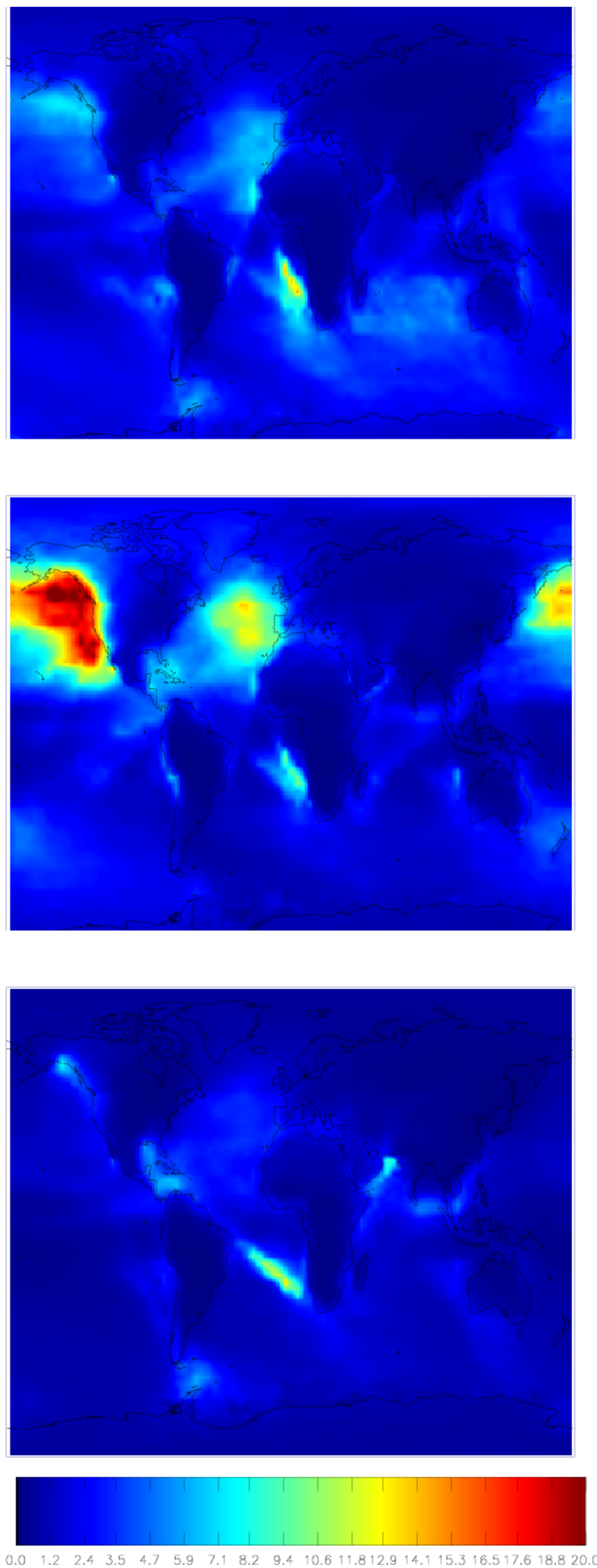

Fig. 13. Yearly average contribution (\%) to wet deposition of nitrate from bulk ships (upper), container ships (middle) and oil tankers (bottom).
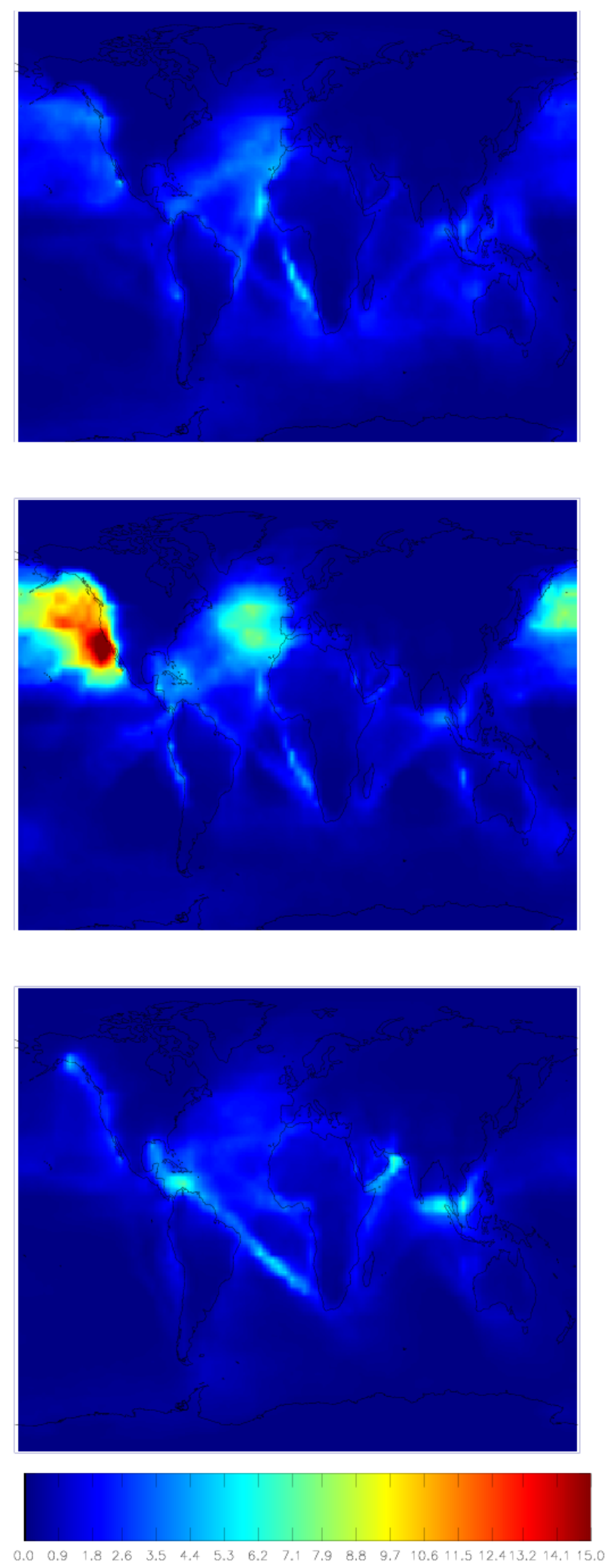

Fig. 14. Yearly average contribution (\%) to wet deposition of sulphur from bulk ships (upper), container ships (middle) and oil tankers (bottom). 
Western Europe/north western tip of Africa. Over South Western Europe/north western tip of Africa the contribution reaches $5-10 \%$ whereas for the coast of Western North America it could be as high as 10-20\%. The impact of sulphur wet deposition (Fig. 14) follows a very similar geographical pattern to that described above for nitrate wet deposition. However, the maximum relative contributions are lower for sulphur than nitrate.

Figure 9 shows the changes in $\mathrm{OH}$ and methane lifetime due to the inclusions of the different ship types compared to runs where emissions from these types are excluded. The container ships, which have the largest emissions (Table 5), also result in the largest changes of these components. Global yearly averaged $\mathrm{OH}$ increases by $0.75 \%$ and methane lifetime is reduced by $1.12 \%$. The tanker traffic, which has a quite strong signal in the tropics (discussed for ozone above) has a slightly more efficient methane lifetime change if one weight it by the global $\mathrm{OH}$ change. This could be expected as the loss rate of methane with $\mathrm{OH}$ is favoured at high temperatures.

The impacts of each ship type are not necessarily proportional to the amounts emitted. The severity of the impacts depend on factors such as geographical and seasonal traffic distribution, distance from coast or populated areas, vulnerability of ecosystems in impact regions, meteorological factors, and nonlinear chemistry related to background pollution levels. With regard to regulations it could therefore be of interest to study the impact of ship types per unit emissions. If one for instance wants to take a global measure to reduce acidification it could be that reducing the emissions for one ship type a certain amount would be more efficient than reducing equivalently for another. We therefore divided the impacts discussed in the previous section with the total global emissions for each of the three ship types. We assumed that the ozone production due to ship emissions is mainly $\mathrm{NO}_{\mathrm{x}}$ limited. This is due to low emissions of $\mathrm{CO}$ and VOCs and often low background $\mathrm{NO}_{\mathrm{x}}$ levels over most Oceanic areas. The hypothesis was tested and discussed in Endresen et al. (2003). We have therefore divided the July surface ozone contribution for the three major ship types with their respective global $\mathrm{NO}_{\mathrm{x}}$ emissions in Fig. 15. In order to reduce the contribution of ship emissions to surface ozone over the western coast of North America it would be most efficient to regulate the emissions form container ships. A different option, not discussed further here, would be to regulate the traffic. The tanker vessels contribute relatively much to tropical surface ozone compared to the other ship types. However the total contribution from ship traffic to tropical ozone (Fig. 8 and Fig. 11) is limited. Container traffic has the largest contribution to column ozone, as can be seen in Fig. 12. Comparing Fig. 12 with Fig. 16 it can be seen that this is mainly because it has the largest emissions. Per unit emitted the effects of the different ship types on column ozone are more equal in magnitude (Fig. 16). For acidification the contribution from ship emissions are mainly large over Scandinavia, North Western America, Western Europe, North Western Africa and Malaysia/Indonesia (Fig. 8). For Western North America, South Western Europe and Western Africa container traffic contributes the most per unit sulphur and nitrogen emitted (Figs. 17 and 18). But bulk ships and tank vessels are clearly also of some importance. Tank vessels are the dominant contributors to acidification over Indonesia and Malaysia. For Scandinavia and North Western Europe where contribution to acidification and ozone from ships also is significant (Fig. 8) the three major ship types show weak impact signals. We therefore conclude that in this region the effects are dominated by other and somewhat smaller ship types that also tend to operate closer to the coast. For $\mathrm{OH}$ and methane lifetime changes, bulk ships lead to the largest changes per amount of nitrogen emitted (Fig. 19). This is probably due to the traffic pattern, bulk ships operate more in low polluted regions (Southern Hemisphere) where $\mathrm{OH}$ formation shows stronger response to $\mathrm{NO}_{\mathrm{x}}$ perturbations.

\section{Conclusion}

The recent public focus on anthropogenic emissions and climate change has lead to an unprecedented level of commitment to reduce emissions by industry actors and policy makers. The shipping industry is no exception. Reliable emission inventories are a fundamental input to evaluating the impact of emission on the environment and human health and to guide the industry and the policy makers on mitigation options. However, the actual levels of emissions and impacts from ocean-going ships are subject to an ongoing scientific debate. The need for better operational data as input to fleet modelling has been stressed by several studies.Our study shows that available operational data indicate a strong dependency on ship type and size for the activity profiles, with average number of days at sea decreasing from 280 days for large cargo vessels to 130 days for small cargo vessels. The variation in traffic and emissions between different months seems to be as much as $10 \%$. Ship type specific modelling shows that the oil tankers, container carriers and bulk vessels consume about $50 \%$ of the marine bunker used by the world fleet of ocean going vessels. The total fuel consumption is estimated to about $217 \mathrm{Mt}$. Of this, approximately $5 \%$ or 11 Mt is consumed in ports. Some studies have questioned the reported sale of marine bunkers, and reported significantly higher estimates based on fleet modelling. This study does not find any evidence for such high estimates. We provide evidence here to suggest that the input data to fleet modelling have to be based on activity and movement data, and not on limited data from engine manufactures for large ships.

This study confirms earlier studies indicating that ship emissions have a significant contribution to the concentration of a number of atmospheric pollutants and greenhouse gases. 

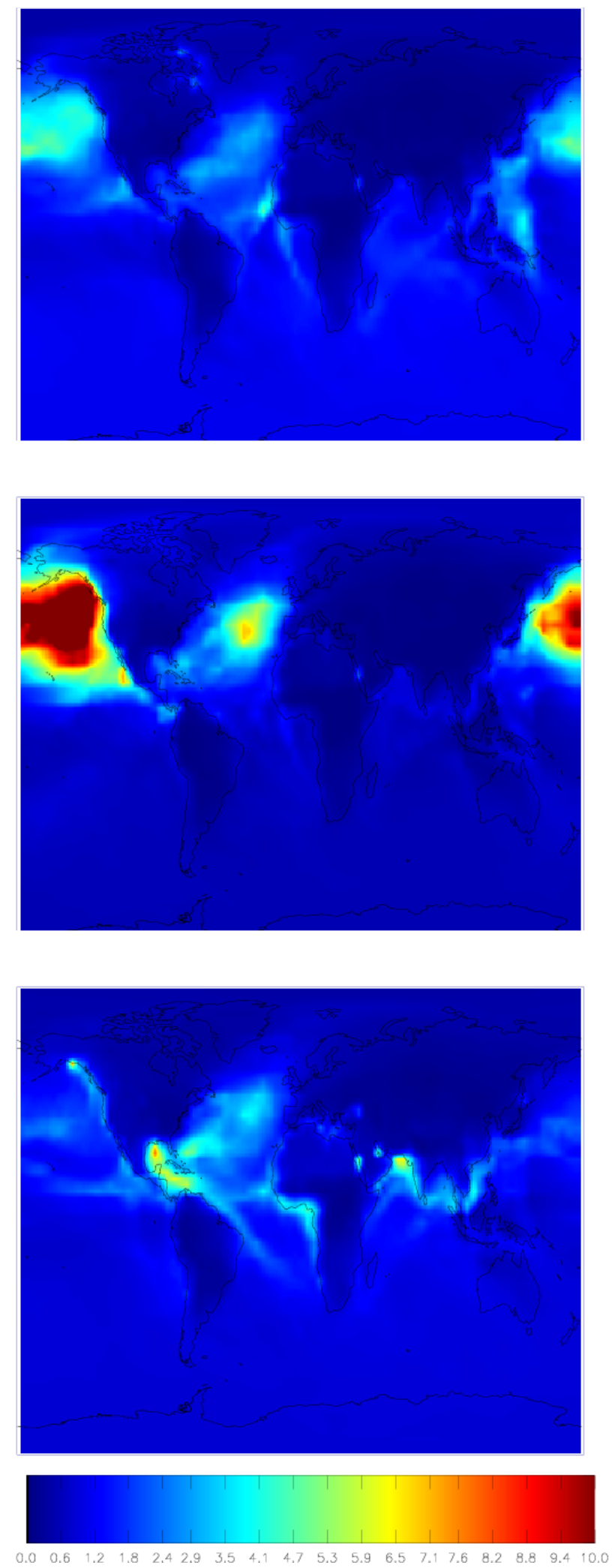

Fig. 15. July average contribution (\%) to surface ozone divided by global nitrogen emissions $(\mathrm{Tg}(\mathrm{N}))$ for bulk ships (upper), container ships (middle) and oil tankers (bottom).
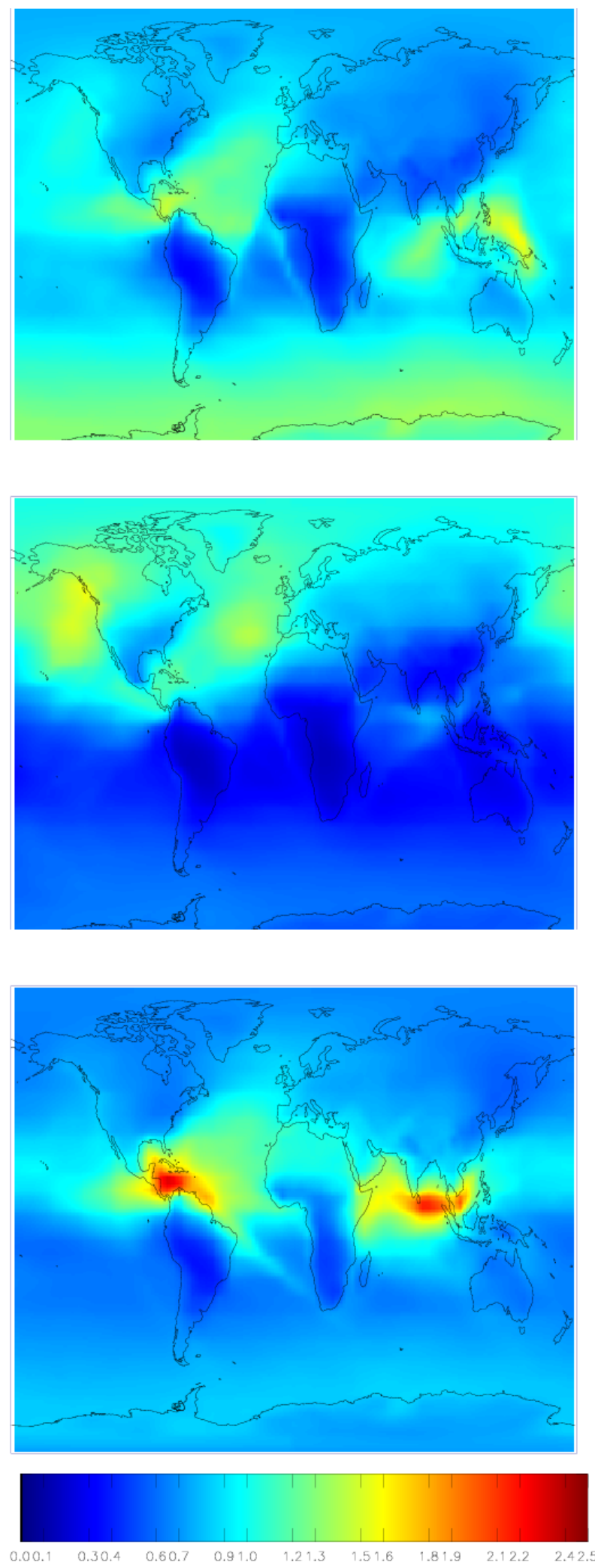

Fig. 16. Yearly average contribution (\%) to column ozone divided by global nitrogen emissions $(\mathrm{Tg}(\mathrm{N}))$ for bulk ships (upper), container ships (middle) and oil tankers (bottom). 

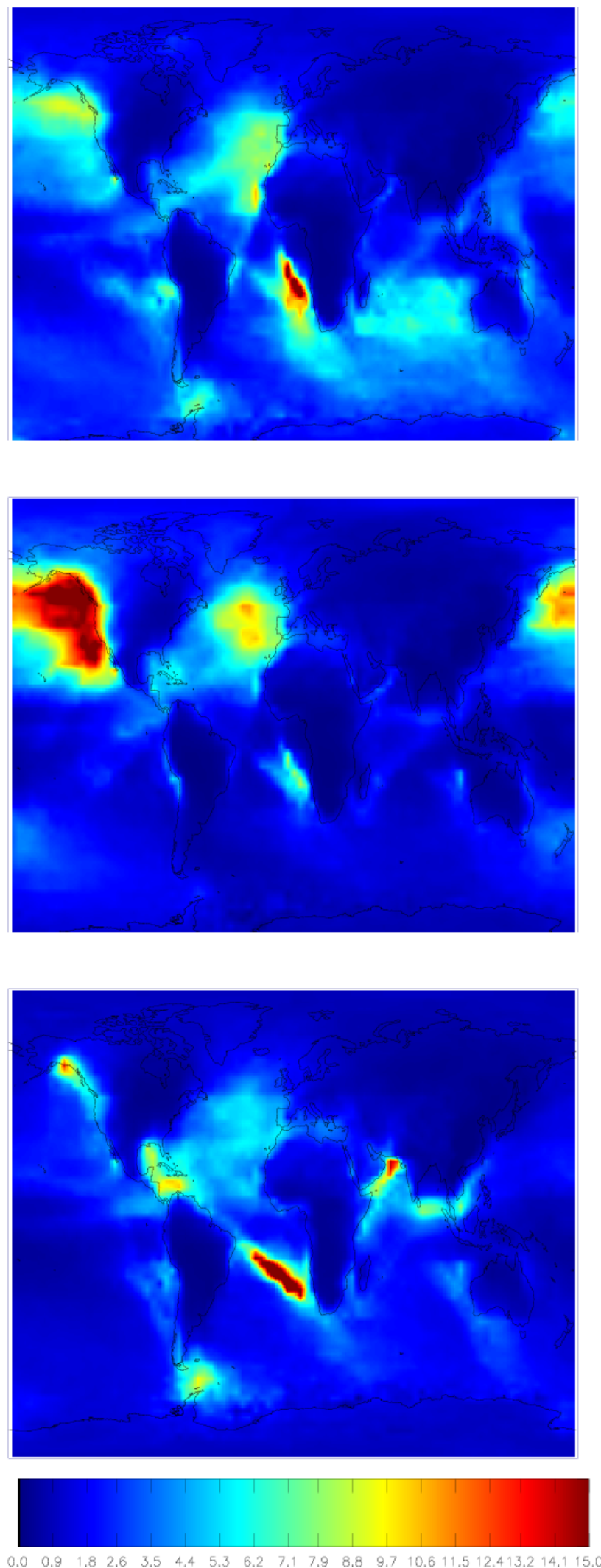

Fig. 17. Yearly average contribution (\%) to nitrate wet deposition divided by global nitrogen emissions $(\mathrm{Tg}(\mathrm{N}))$ for bulk ships (upper), container ships (middle) and oil tankers (bottom).
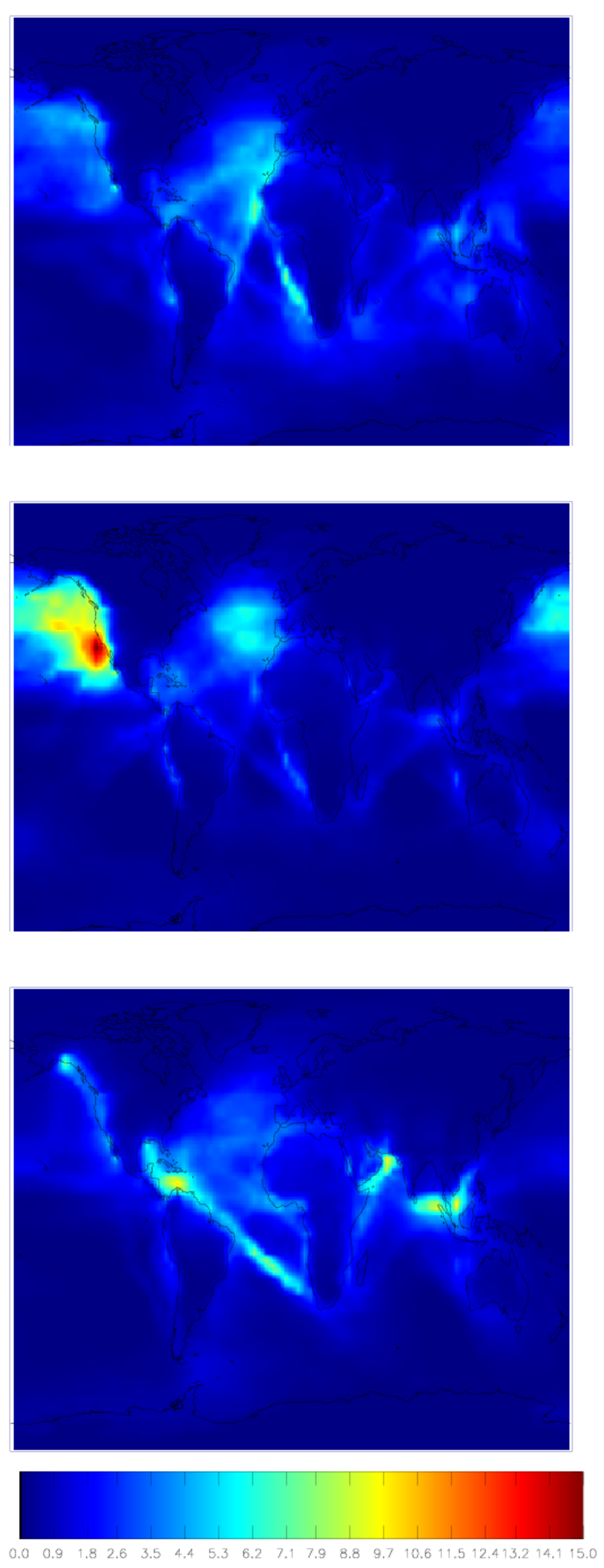

Fig. 18. Yearly average contribution (\%) to sulphur wet deposition divided by global sulphur emissions $(\operatorname{Tg}(\mathrm{S}))$ for bulk ships (upper), container ships (middle) and oil tankers (bottom). 


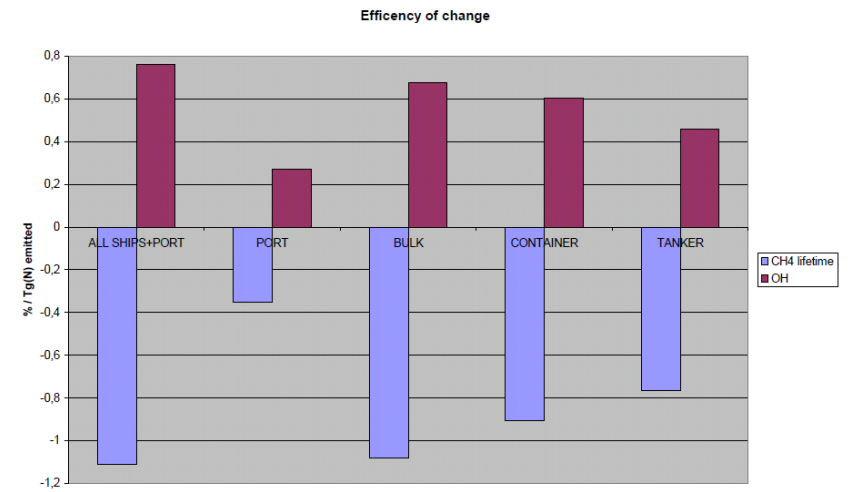

Fig. 19. Changes in $\mathrm{OH}$ and methane lifetime divided by the nitrogen emissions compared to simulations where the noted ship-types are excluded.

Ship emissions are a strong contributor over much of the world Oceans to surface concentrations of primary components, especially $\mathrm{NO}_{2}$ and $\mathrm{SO}_{2}$. The contribution to $\mathrm{NO}_{2}$, $\mathrm{SO}_{2}, \mathrm{BC}$ and $\mathrm{OC}$ is also large over some coastal zones. Secondary species formed from the effluents in the ship emissions have longer chemical lifetimes and are transported in the atmosphere over several hundreds of kilometres. Thereby they can contribute to air quality problems on land. In general an emission perturbation is most effective in increasing ozone formation in regions with low background pollution. For surface ozone the ship contribution is therefore high over the background Oceans. But it might also be of significance over Western North America (contribution 15-25\%), Western Europe (5-15\%) and parts of the other continents. Ozone perturbations in the upper troposphere are more important with regard to radiative forcing. A very simplified measure of the ship impact to ozone as a greenhouse gas is the contribution to the tropospheric column which we find to be up to 5-6\%. Ship emissions increase the $\mathrm{OH}$ radical (by $3.67 \%$ in global yearly average) which is the major reactant initiating removal cycles of atmospheric methane. As the direct emissions of methane from ships are small, the ship traffic results in lower concentrations of this greenhouse gas in the atmosphere. The global methane lifetime is reduced with $5.35 \%$ or $7.5 \%$ if a feedback factor is accounted for. Deposition of sulphur and nitrogen compounds, may cause acidification of natural ecosystems and freshwater bodies and threaten biodiversity through excessive nitrogen input (eutrophication) (Vitousek et al., 1997; Galloway et al., 2004; Bouwman et al., 2002). Our calculations show that ships contribute $11 \%$ to nitrate wet deposition and $4.5 \%$ to sulphur wet deposition globally. The contribution to nitrate wet deposition reaches $25-50 \%$ over North-Western North America and Scandinavia. For South-Western Europe and north-Western Africa the contribution is $25-35 \%$. The sulphur deposition is also high in the same regions contributing $15-25 \%$ and $15-20 \%$ respectively.
With regard to the efficiency of possible emission regulations it is also of interest to see how different geographical operation profiles of major ship types impact particular regions or vulnerable areas. Compared to the two other major ship types, bulk carriers show larger impacts in Oceania which is one of the export regions. The container ships have large impact over the northern mid-latitude Oceans where the trades between the major economic regions of the world occur. The tank vessels are characterized by having their largest impact at low latitudes, near the export regions the Gulf of Mexico and the Middle East propagating along the ship-lines of the Indian Ocean towards East Asia. For surface ozone in July the contribution of bulk ships is less than 5\% everywhere. With regard to pollution levels over populated areas the contribution is only a few percent over most coastal regions. The contribution of the container traffic is large over the Atlantic and in particular the Pacific Oceans on the trades between North America and Asia. Though the contribution from the container traffic decreases rapidly inland from the coast, the container ships seem to have a significant impact on the surface ozone levels in coastal zones of Western North America. The contribution from the tanker traffic is smaller but up to 3-5\% in the Arabian Sea and Gulf of Mexico. The container traffic is the ship type with the largest total emissions and also the largest impact for all components. The bulk ships have the largest contribution of the three ship types at high southern latitudes. The contribution is mainly high during the Southern Hemisphere summer when there is traffic to and from Antarctica. Wet deposition of acidic components is most critical over land, estuaries and coastal zones where they may cause acidification in regions with low buffering capacity. Bulk ships and tank vessels contribute up to $3-7 \%$ to wet deposition of nitrate on the west coast of America, and also parts of the eastern coast of the continent. The contribution is similar over coastal zones of Europe, Africa and Australia and small regions of Asia. In addition to this the container traffic has a much larger impact over Western North America and South Western Europe/north western tip of Africa. Over South Western Europe/North western tip of Africa the container contribution reaches $5-10 \%$ whereas for the coast of Western North America it could be as high as $10-20 \%$. The impact of sulphur wet deposition follows a very similar geographical pattern to that described for nitrate but the relative perturbations are slightly lower.

Though one ship type shows larger impacts than another the impacts of each ship type are not necessarily proportional to the amounts emitted. This is due to a number of factors discussed in Sect. 8. We therefore made calculations of the relative contributions per unit of pollutant emitted globally. However, some of our conclusions from our non-emission weighted impact calculations (discussed paragraph above) holds. One example is that in order to reduce the contribution of ship emissions to surface ozone over the western coast of North America it would be most efficient to regulate the emissions from container ships. The tanker 
vessels contribute relatively much to tropical surface ozone compared to the other ship types, however the total contribution from ship traffic to tropical ozone is limited. Per unit emitted the effects of the different ship types on column ozone are more equal in magnitude. Regarding acidification in Western North America, South Western Europe and Western Africa container traffic contributes the most per unit sulphur and nitrogen emitted. But bulk ships and tank vessels are clearly also of some importance. Tank vessels are the dominant contributors to acidification over Indonesia and Malaysia. Interestingly, for Scandinavia and north Western Europe where impacts on acidification and ozone from ships are very evident the contribution from the three major ship types is moderate. Other ships participating in more coastal operations are likely to be the main contributors in this region.

We find that our new inventory of global port emissions has to be considered when performing impact modelling. At least for $\mathrm{NO}_{2}$ and $\mathrm{SO}_{2}$ port emissions seem to be of significance. For most ports the contribution to the two components is in the range $0.5-5 \%$, for a few ports it exceeds $10 \%$. Due to nonlinearity in the chemistry it is not necessarily the largest ports that have the largest contribution since some of these already are situated in quite polluted regions.

Acknowledgements. This study uses input data from the EU project Quantify and is part of the Norwegian Research Council project MAMI.

Edited by: R. Ebinghaus

\section{References}

AMVER: Global ship observations for a full year from August 2001 to August 2002 provided by AMVER (http://www.amver.com/ statarchive.htm), through personal correspondence with Carroll, E., 2005.

Beirle, S., Platt, U., von Glasow, R., Wenig, M., and Wagner, T.: Estimate of nitrogen oxide emissions from shipping by satellite remote sensing, Geophys. Res. Lett., 31, L18102, doi:10.1029/2004GL020312, 2004.

Berntsen, T. and Fuglestvedt, J.: Global temperature responses to current emissions from the transport sectors, Proc. Natl. Acad. Sci. USA 105, 19154-19159, 2008.

Capaldo, K., Corbett, J. J., Kasibhatla, P., Fischbeck, P. S., and Pandis, S. N.: Effects of ship emissions on sulphur cycling and radiative climate forcing over the ocean, Nature 400, 743-746, 1999.

Chen, G., Huey, L. G., Trainer, M., et al: An investigation of the chemistry of ship emission plumes during ITCT 2002, J. Geophys. Res., 110, D10S90, doi:10.1029/2004JD005236, 2005.

COADS: Global ship observations for year 2000 provided by COADS (http://dss.ucar.edu/pub/COADS_intro.html), through personal correspondence with Worley, S. J., 2005.

Cofala, J., Amann, M., Heyes, C., Klimont, Z., Posch, M., Schöpp, W., Tarasson, L., Jonson, J., Whall, C., and Stavrakaki, A.: Final Report: Analysis of Policy Measures to Reduce Ship Emissions in the Context of the Revision of the National Emissions Ceilings
Directive; International Institute for Applied Systems Analysis: Laxenburg, Austria, March 2007, p. 74, 2007.

Collins, W. J., Sanderson, M. G., and Johnson, C. E.: Impact of increasing ship emissions on air quality and deposition over Europe by 2030. Meteorologische Zeitschrift, published online, doi:10.1127/0941-2948/2008/0296, 2008.

Cooper, D.A.: Exhaust emissions from ships at berth, Atmos. Environ., 37(27), 3817-3830, 2003.

Corbett, J. J., Winebrake, J. J., Green, E. H., Kasibhatla, P., Eyring, V., and Lauer, A.: Mortality from Ship Emissions: A Global Assessment. Environ. Sci. Technol., 41(24), doi: 0.1021/es071686z, 8512-8518, 2007.

Corbett, J. J. and Koehler, H. W.: Considering alternative input parameters in an activity-based ship fuel consumption and emissions model: Reply to comment by Endresen, $\varnothing$.. et al. on "Updated emissions from ocean shipping", J. Geophys. Res., 109, D23303, doi:10.1029/2004JD005030, 2004.

Corbett, J. J. and Koehler, H. W.: Updated emissions from ocean shipping, J. Geophys. Res. Atmos., 108, doi:10.1029/2003JD003751, 2003.

Corbett, J. J., Fischbeck, P. S., and Pandis, S. N.: Global Nitrogen and Sulfur Emissions Inventories for Oceangoing Ships, J. Geophys. Res., 104(D3) 3457-3470, 1999.

Dalsøren, S. B. and Isaksen, I. S. A.: CTM study of changes in tropospheric hydroxyl distribution 1990-2001 and its impact on methane, Geophys. Res. Lett., 33, L23811, doi:10.1029/2006GL027295, 2006.

Dalsøren, S. B., Endresen, Ø., Isaksen, I. S. A., Gravir, G., and Sørgård, E.: Environmental impacts of the expected increase in sea transportation, with a particular focus on oil and gas scenarios for Norway and northwest Russia, J. Geophys. Res., 112, D02310, doi:10.1029/2005JD006927, 2007.

Derwent, R. G, Stevenson, D. S., Doherty, R. M., Collins, W. J., Sanderson, M. G., Johnson, C. E., Cofala, J., Mechler, R., Amann, M., and Dentener, F. J.: The contribution from ship emissions to air quality and acid deposition in Europe, Ambio, 34(1), 54-59, 2005.

Devasthale, A., Krüger, O., and Graß1, H.: Impact of ship emissions on cloud properties over coastal areas, Geophys. Res. Lett., 33, L02811, doi:10.1029/2005GL024470, 2006.

Durkee, P. A., Noone, K. J., and Bluth, R. T.: The Monterey Ship Track Experiment, J. Atmos. Sci., 57, 2523-2541, 2000 b.

Energy Information Administration (EIA), World Apparent Consumption of Refined Petroleum Products, (http://www.eia.doe. gov/pub/international/iea2005/Table35.xls); World Petroleum Supply and Disposition 2000 (http://www.eia.doe.gov/emeu/iea/ Table31.html), downloaded 2007, 2004.

Emberson, L. D., Ashmore, M. R., Murray, F, Kuylenstierna, J. C. I., Percy, K. E., Izuta, T, Zheng, Y., Shimizu, H., Sheu, B. H., Liu, C. P., Agrawal, M., Wahid, A., Abdel-Latif, N. M., van Tienhoven, M., de Bauer, L. I., and Domingos M.: Impacts of air pollutants on vegetation in developing countries, Water Air Soil Poll., 130, 107-118, 2001.

EMEP/CORINAIR: EMEP/CORINAIR, Emission Inventory Guidebook - 3rd edition October 2002 UPDATE, Technical report No. 30, Shipping Activities - Sub sector 0804, European Environment Agency, Copenhagen, Denmark, 2002, available at: http://reports.eea.eu.int/EMEPCORINAIR3/en/B842vs3.4.pdf, 2002. 
Endresen, Ø., Sørgård, E., Bakke, J., and Isaksen, I. S. A.: Comment on "Updated Emissions from Ocean Shipping" by Corbett, J. J. and Koehler, H. W., J. Geophys. Res., 109, D23302, doi:10.1029/2004JD004853, 2004.

Endresen, Ø., Sørgård, E., Behrens, H. L., and Brett, P. O.: A historical reconstruction of ships' fuel consumption and emissions, J. Geophys. Res., 112, D12301, doi:10.1029/2006JD007630, 2007.

Endresen, Ø., Sørgård, E., Sundet, J. K., Dalsøren, S. B., Isaksen, I. S. A., Berglen, T. F., and Gravir, G.: Emission from international sea transportation and environmental impact, J. Geophys. Res., 108(D17), 4560, doi:10.1029/2002JD002898, 2003.

Endresen, Ø., Dalsøren, S., Eide, M., Sørgård, E., and Isaksen, I. S. A.: The environmental impacts of increased international maritime shipping - Past trends and future perspectives, Chapter in OECD book, accepted 2009.

Environmental Protection Agency (EPA): Analysis of Commercial Marine Vessels Emission and Fuel Consumption Data, Office of Transportation and Air Quality, Rep. EPA420-R-00-002, February 2000, available at: http://www.epa.gov/otaq/models/ nonrdmdl/c-marine/r00002.pdf, 2000.

EPA (Environmental Protection Agency): National Air Quality and Emissions Trends Report, 2003 Special Studies Edition, http:// www.epa.gov/air/airtrends/aqtrnd03, 2003.

Eyring, V., Köhler, H. W., van Aardenne, J., and Lauer, A.: Emissions from international shipping: 1 . The last 50 years, J. Geophys. Res., 110, D17305, doi:10.1029/2004JD005619, 2005.

Eyring, V., Stevenson, D. S., Lauer, A., Dentener, F. J., Butler, T., Collins, W. J., Ellingsen, K.,Gauss, M., Hauglustaine, D. A., Isaksen, I. S. A., Lawrence, M. G., Richter, A., Rodriguez, J. M., Sanderson, M., Strahan, S. E., Sudo, K., Szopa, S., van Noije, T. P. C., and Wild, O.: Multi-model simulations of the impact of international shipping on atmospheric chemistry and climate in 2000 and 2030, Atmos. Chem. Phys., 757-780, 2007.

Eyring, V., Isaksen, I. S. A., Berntsen, T., Collins, W. J., Corbett, J. J., Endresen, Ø, Grainger, R. G., Moldanova, J., Schlager, H., and Stevenson, D. S.: Assessment of Transport Impacts on Climate and Ozone: Shipping, Atmos. Environ., under review, 2009.

Fearnleys, Review 2007, Fearnresearch, Oslo, Norway, 92 pp., 2008.

Ferek, R. J., Garrett, T., Hobbs, P. V., Strader, S., Johnson, D., Taylor, J. P., Nielsen, K., Ackermann, A. S., Kogan, Y., Liu, Q., Albrecht, B. A., and Babb, D.: Drizzle Suppression in Ship Tracks, J. Atmos. Sci., 57, 2707-2728, 2000.

Flodström, E.: Energy and emission factors for ships in operation, Mariterm AB, Swedish Transport and Communications Research Board, KFB report 1997, 24, 1997.

Fuglestvedt, J. S., Berntsen, T., Myhre, G., Rypdal, K., and Skeie, R. B.: Climate forcing from the Transport Sectors. Proceedings of the National Academy of Sciences (PNAS), 105(2), 454-458, 2008.

Galloway, J. N., Dentener, F. J., Capone, D. G., Boyer, E. W., Howarth, R. W., Seitzinger, S. P., Asner, G. P., Cleveland, C., Green, P., Holland, E., Karl, D. M., Michaels, A. F., Porter, A. H., Townsend, A., and Vörösmarty, C.: Nitrogen Cycles: Past, Present and Future, Biogeochemistry, 70(2), 153-226, 2004.

HEI: HEI International Scientific Oversight Committee. Health Effects of Outdoor Air Pollution in Developing Countries of Asia: A Literature Review, Special Report 15, Health Effects Institute,
Boston, MA, USA, 2004.

Hobbs, P. V., Garrett, T. J., Ferek, R. J., Strader, S. R., Hegg, D. A., Frick, G. M., Hoppel, W.A., Gasparovic, R. F., Russell, L. M., Johnson, D. W., O’Dowd, C., Durkee, P. A., Nielsen, K. E., and Innis, G.: Emissions from Ships with their respect to clouds, J. Atmos. Sci., 57, 2570-2590, 2000.

Hoffmann J. and Kumar, S.: Globalization: the maritime nexus, in the Handbook of Maritime Economics and Business, edited by: Grammenos, C., 35-62, London, LLP, UK, October 2002, 2002.

International Energy Agency (IEA): Sale of marine fuel, period 2001 to 2005, Paris, France, 2007.

International Maritime Organisation (IMO): Report on the outcome of the comprehensive study undertaken by the informal cross government/industry scientific group of experts established to evaluate the effects of the different fuel options proposed under the revision of MARPOL ANNEX VI. BLG 12/6/1, 20 December 2007, 2007.

Isaksen, I. S. A., Hov, Ø., and Hesstvedt, E.: Ozone generation over rural areas, Environ. Sci. Tech., 12, 1279-1284, 1978.

Isaksen, I. S. A., Zerefos, C., Kourtidis, K., Meleti, C., Dalsøren, S. B., Sundet, J. K., Grini, A., Zanis, P., and Balis, D.: Tropospheric ozone changes at unpolluted and semipolluted regions induced by stratospheric ozone changes, J. Geophys. Res., 110, D02302, doi:10.1029/2004JD004618, 2005.

Isakson, J., Persson, T. A., and Lindgren, E. S.: Identification and assessment of ship emissions and their effects in the harbour of Goteborg, Sweden, Atmos. Environ., 35, 3659-3666, 2003.

Kasibhatla, P., Levy II, H., Moxim, W. J., Pandis, S. N., Corbett, J. J., Peterson, M. C., Honrath, R. E., Frost, G. J., Knapp, K., Parrish, D. D., and Ryerson, T. B.: Do emissions from ships have a significant impact on concentrations of nitrogen oxides in the marine boundary layer, Geophys. Res. Lett., 27, 2229-2232, 2000.

Lauer, A., Eyring, V., Hendricks, J., Jöckel, P., and Lohmann, U.: Effects of ocean-going shipping on aerosols and clouds, Atmos. Chem. Phys., 7, 5061-5079, 2007, http://www.atmos-chem-phys.net/7/5061/2007/.

Lee, D. S., Lim, L. L., Eyring, V., Sausen, R., Endresen, Ø., and Behrens, H. L.: Radiative forcing and temperature response from shipping. In: Proceedings of the International Conference on Transport, Atmosphere and Climate (TAC), Oxford, UK, 208213, 2007.

Lelieveld, J., Peters, W., Dentener, F. J., and Krol, M. C.:, Stability of tropospheric hydroxyl chemistry, J. Geophys. Res., 107, 4715, doi:4710.1029/2002JD002272, 2002.

Lawrence, M. G. and Crutzen, P. J.: Influence of $\mathrm{NO}_{\mathrm{x}}$ Emissions from ships on tropospheric photochemistry and climate, Nature, 402(6758), 167-170, 1999.

Lelieveld, J., van Aardenne, J., Fischer, H., de Reus, M., Williams, J., and Winkler, P.: Increasing Ozone over the Atlantic Ocean, Science, 304, 1483-1487, 2004.

Lin, X., Trainer, M., and Liu, S. C.: On the nonlinearity of the tropospheric ozone production, J. Geophys. Res., 93(D12), 1587915888, 1988.

Lloyd's MIU (LMIU): Extract from the vessel movement database 2003 (January, April, July and October), 2004.

Lloyd's Register of Shipping (LR): Marine Exhaust Emissions Quantification Study - Baltic Sea, Report No. 98/EE/7036, 1998. Lloyd's Register of Shipping (LR): Marine Exhaust Emissions Re- 
search Programme, Lloyd's Register Engineering Services, London, UK, 1995.

Lloyds Register Fairplay (LRF): Extract from the world fleet database (all civil ocean-going cargo and passenger ships above or equal to 100 GT), Redhill, UK, 2004.

Lloyd's Register Fairplay (LRF): Extracts from the world merchant fleet database (all civil ocean-going cargo and passenger ships above or equal to $100 \mathrm{GT}$ ), Redhill, UK, 2007.

Lui, S. C., Trainer, M., Fehsenfeld, F. C., Parrish, D. D., Williams, E. J., Fahey, D. W., Hubler, G., and Murphy, P. C.: Ozone production in the rural troposphere and the implications for regional and global ozone distributions, J. Geophys. Res. 92(D4), 41914207, 1987.

Marmer, E. and Langmann, B.: Impact of ship emissions on the Mediterranean summertime pollution and climate: A regional model study, Atmos. Environ., 39, 4659-4669, 2005.

McCulloch, A. and Lindley, A. A.: From mine to refrigeration: a life cycle inventory analysis, 26(8), 865-872, 2003.

Martuzzi, M., Krzyzanowski, M., and Bertollini, R.: Health impact assessment of air pollution: providing further evidence for public health action, Eur. Respir. J., 21, 86S-91S, 2003.

Nel, A.: Air Polution-Related Illness: Biomolecular Effects of Particles, Science, 208, 804, 2005.

Mauzerall, D. L. and Wang, X.: Protecting Agricultural Crops from the Effects of Tropospheric Ozone Exposure : Reconciling Science and Standard Setting in the United States, Europe and Asia, Ann. Rev. Energy Environ., 26, 237-268, 2001.

Penner J. E., Andreae, M., Annegarn, H., et al.: Chapter 5. Aerosols, their direct and indirect effects, in: "Climate Change 2001: The Scientific Basis”, edited by: Houghton, J. T., Ding, Y., Griggs, D. J., et al., Cambridge University Press, 289-347, 2001.

Petzold, A., Feldpausch, P., Fritzsche, L., Minikin, A., Lauer, A., and Bauer, H.: Particle Emissions from Ship Engines, J. Aerosol Sci., 35, 1095-1096, 2004.

Parrish, D. D., Millet, D. B., and Goldstein, A. H.: Increasing ozone in marine boundary layer inflow at the west coasts of North America and Europe, Atmos. Chem. Phys., 9, 1303-1323, 2009, http://www.atmos-chem-phys.net/9/1303/2009/.

Petzold, A., Hasselbach, J., Lauer, P., Baumann, R., Franke, K., Gurk, C., Schlager, H., and Weingartner, E.: Experimental studies on particle emissions from cruising ship, their characteristic properties, transformation and atmospheric lifetime in the marine boundary layer, Atmos. Chem. Phys., 8, 2387-2403, 2008, http://www.atmos-chem-phys.net/8/2387/2008/.

Prather, M., Dentener, F., Derwent, R., et al.: Atmospheric chemistry and greenhouse gases, Climate Change 2001: The Scientific Basis, edited by: Houghton, J. T., Ding, Y., Griggs, D. J., et al., Cambridge University Press, Cambridge, UK, 239-287, 2001.

Ramanathan, V., Crutzen, P. J., Kiehl, J. T., and Rosenfeld, D., Aerosols, Climate, and The Hydrological Cycle, Science, 294, 2119-2124, 2001.

Ramaswamy, V., Boucher, O., Haigh, J., et al.: Chapter 6, Radiative Forcing of Climate Change, in Climate Change 2001: The Scientific Basis, edited by: Houghton, J. T., Ding, Y., Griggs, D. J. et al., Cambridge University Press, Cambridge, 349-416, 2001.

Richter, A., Eyring, V., Burrows, J. P., Bovensmann, H., Lauer, A., Sierk, B., and Crutzen, P. J.: Satellite measurements of NO2 from international shipping emissions, Geophys. Res. Lett., 31,
L23110, doi:10.1029/2004GL020822, 2004.

Rodrigue, J.-P., Comtois, C., and Snack, B.: The geography of transport systems, Routledge, New York, USA, ISBN-100-41535441-2, 286 pp., 2006.

Saxe, H. and Larsen, T.: Air pollution from ships in three Danish ports, Atmos. Environ, 38, 4057-4067, 2004.

Sausen, R., Isaksen, I., Grewe, V., Hauglustaine, D., Lee, D. S., Myhre, G., Köhler, M. O., Pitari, G., Schumann, U., Stordal, F., and Zerefos, C.: Aviation radiative forcing in 2000: An update on IPCC (1999), Meteorologische Zeitschrift, 14(7), 555$561,2005$.

Schreier, M., Kokhanovsky, A. A., Eyring, V., Bugliaro, L., Mannstein, H., Mayer, B., Bovensmann, H., and Burrows, J. P.: Impact of ship emissions on the microphysical, optical and radiative properties of marine stratus: a case study, Atmos. Chem. Phys., 6, 4925-4942, 2006,

http://www.atmos-chem-phys.net/6/4925/2006/.

Schreier, M., Mannstein, H., Eyring, V., Bovensmann, H., Global ship track distribution and radiative forcing from 1year of AATSR-data, Geophys. Res. Lett., 34, L17814, doi:10.1029/2007GL030664, 2007.

Sinha, P., Hobbs, P. V., Yokelson, R. J., Christian, T. J., Kirchstetter, T. W., and Bruintjes, R.: Emissions of trace gases and particles from two ships in the southern Atlantic Ocean, Atmos. Environ., 37(15), 2139-2148, doi:10.1016/S1352-2310(03)00080-3, 2003.

Song, C. H., Chen, G., Hanna, S. R., Crawford, J., and Davis, D. D.: Dispersion and chemical evolution of ship plumes in the marine boundary layer: Investigation of $\mathrm{O}_{3} / \mathrm{NO}_{\mathrm{y}} / \mathrm{HO}_{\mathrm{x}}$ chemistry, J. Geophys. Res., 108(D4), 4143, doi:10.1029/2002JD002216, 2003.

United Nations Conference on Trade and Development (UNCTAD): Review of Maritime Transport 2007, ISBN: 978-92-1112725-6, New York (online available at http://www.unctad.org/ Templates/WebFlyer.asp?intItemID=4398\&lang=1), 2007.

Vitousek, P. M., Aber, J., Howarth, R. W., Likens, G. E., Matson, P. A., Schindler, D. W., Schlesinger W. H., and Tilman, G. D, "Human Alteration of the Global Nitrogen Cycle: Causes and Consequences", Issues in Ecology, 1, 1-17, 1997.

von Glasow, R., Lawrence, M. G., Sander, R., and Crutzen, P. J.: Modelling the chemical effects of ship exhaust in the cloud-free marine boundary layer, Atmos. Chem. Phys., 3, 233-250, 2003, http://www.atmos-chem-phys.net/3/233/2003/.

Wang, Y. H. and Jacob, D. J.: Anthropogenic forcing on tropospheric ozone and $\mathrm{OH}$ since preindustrial times, J. Geophys. Res., 103, 123-131, 1998.

Whall, C., Cooper, D., Archer, K., et al.: Quantification of emissions from ships associated with ship movements between ports in the European Community, Rep. 06177.02121, Entec, Northwich, UK, 2002.

WHO: Health aspects of air pollution with particulate matter, ozone and nitrogen dioxide, Report on a WHO working group, EUR/03/5042688, 98 pp., 2003.

WMO: WMO statement on the status of the global climate in 1996, No. 858, World Meteorological Organization, ISBN: 9263-10858-7, 12 pp., 1997. 